\title{
Entre Demandas de Direitos e a "Peça de Defesa Padrão": uma análise dos Conflitos nos Juizados Especiais Federais do Rio de Janeiro
}

\author{
Between Rights Claims and the "Standard Defense Piece": an \\ analysis of the Conflicts in the Special Federal Courts of Rio de \\ Janeiro
}

Maria Stella Faria de Amorim ${ }^{1}$

Michel Lobo Toledo Lima ${ }^{2}$

\section{RESUMO}

Este artigo resulta de um conjunto de pesquisas e reflexões realizadas desde 1999 acerca dos Juizados Especiais Estaduais e Federais, desenvolvidas no âmbito da Faculdade de Ciências Jurídicas e Sociais da Universidade Iguaçu, no Programa de Pós-Graduação em Direito da Universidade Gama Filho e no Programa de Pós-Graduação em Direito da Universidade Veiga de Almeida, respectivamente, sendo esta última com projeto de pesquisa, ainda em andamento, executado no Núcleo de Pesquisa em Processos Institucionais de Administração de Conflitos (NUPIAC). Nossas reflexões apontam para a utilização alternada e alternativa de diferentes lógicas que orientam as práticas judiciárias e as interpretações das previsões legais. Lógicas fundadas ora em um direito tido como tradicional, baseado num Estado interventor e tutelar, ora na invocação de um direito tido como moderno, inovador, fundado num Estado mínimo (a exemplo das implementações da justiça restaurativa, dos juizados especiais e das delações premiadas como vias alternativas na administração de conflitos e crimes perante nosso modelo de justiça tradicional). E que, embora sejam diferentes e por vezes até opostas entre si, não se anulam, mas convivem, se sobrepondo uma noutra, por vezes criando modelos híbridos de "justiça", extralegais, conforme os interesses institucionais acerca do caso a ser administrado. Retroalimentam discursos e práticas que fazem, reiteradamente, do novo a reafirmação do velho, no sentido de travestir práticas tradicionais inquisitoriais e hierárquicas no campo do direito com discursos igualitários, modernos e inclusivos (a exemplo dos usos da peça de defesa padrão, observada na pesquisa). Com esse movimento, pretendem legitimar uma

\footnotetext{
1 Doutora e Livre Docente em Sociologia pelo Instituto de Ciências Humanas e Filosofia da Universidade Federal Fluminense (ICHF-UFF); mestre em Antropologia Social no Programa de Pós-Graduação em Antropologia Social da Universidade Federal Fluminense (PPGAS/UFRJ); bacharel e licenciada em Ciências Sociais pela Faculdade de Filosofia da Universidade do Brasil (FFUB); professora titular de Sociologia do Programa de Pós-graduação em Direito da Universidade Veiga de Almeida (PPGD-UVA); pesquisadora do Instituto de Estudos Comparados Em Administração Institucional de Conflitos (INCT/InEAC - UFF). E-mail: stellamorim@ gmail.com.

2 Doutor e mestre em Sociologia pelo Instituto de Estudos Sociais e Políticos da Universidade do Estado do Rio de Janeiro (IESP/UERJ); pós-graduado em Políticas Públicas de Justiça Criminal e Segurança Pública pela Universidade Federal Fluminense (UFF); graduado em Direito pela Pontifícia Universidade Católica do Rio de Janeiro (PUC-Rio); professor visitante do Programa de Pós-graduação em Direito da Universidade Veiga de Almeida (PPGD-UVA); pesquisador de pós-doutorado FAPERJ nota 10 no PPGD-UVA; pesquisador do Instituto de Estudos Comparados Em Administração Institucional de Conflitos (INCT/InEAC - UFF). E-mail: michell_lobo@hotmail.com
} 
burocracia jurídica pessoalizada, sigilosa e que antagoniza práticas, discursos jurídicos e normas vigentes, com o fim de relativizá-los e interpretá-los arbitrariamente, sem limites que não sejam aqueles internos, da ética institucional. Assim, semelhantemente ao que ocorreu, na prática, com o devido processo legal no Brasil, os acordos e as conciliações, tanto nos juizados federais quanto nos estaduais, diferente daquilo que se propõem fazer, nem sempre servem para proteger o cidadão do Estado, mas sim o Estado do cidadão, algo explicitado através dos usos da peça de defesa padrão no campo observado.

\title{
PALAVRAS-CHAVE:
}

Juizados Especiais Federais; peça de defesa padrão; demandas; inquisitorialidade; administração de conflitos.

\begin{abstract}
This article is the result of research and reflections carried out since 1999 on the Special State Courts and Special Federal Courts, developed at the Faculty of Legal and Social Sciences of the Iguaçu University; in the Post-Graduate Program in Law of the Gama Filho University and in the Post-Graduate Program in Law of the Veiga de Almeida University, respectively, the latter with a research project, still in progress, executed in the Center for Research in Institutional Processes of Conflict Administration (NUPIAC). Our reflections demonstrate the alternate and alternative use of different logics that guide judicial practices and the interpretation of laws. Logics based sometimes on a Law considered traditional, based on an intervening and tutelary State, and sometimes on the invocation of a Law considered modern, innovative, based on a minimal State (as in the example of the implementations of restorative justice, special courts, and pre-trial confession as alternative ways to manage conflicts and crimes before our traditional justice model). And although they are different and sometimes even opposed to each other, they do not cancel each other out, but coexist, sometimes overlapping one another, sometimes creating hybrid models of "justice", extralegal, according to the institutional interests about the case to be managed, feeding back discourses and practices that repeatedly make the new the reaffirmation of the old, in the sense of travesty traditional inquisitorial and hierarchical practices in the field of Law with egalitarian, modern and inclusive discourses (as the uses of the "standard defense piece", observed in the research). With this movement, they intend to legitimize a legal bureaucracy that is personalized, secretive, and that antagonizes practices, legal discourses, and current norms, in order to relativize and interpret them arbitrarily, with no limits other than those internal ones, of institutional ethics. Thus, similar to what occurs in practice with due legal process in Brazil, the agreements and conciliations, whether in federal or state courts, unlike what they propose to do, do not always serve to protect the citizen from the State, but to protect the State from the citizen, something made explicit through the uses of the "standard defense piece" in the observed field.
\end{abstract}

\section{KEYWORDS:}

Federal Special Courts. Standard pleading. Demands, Inquisitoriality, Conflict Management. 


\section{INTRODUÇÃO}

No ano de 2021, a lei que instituiu os Juizados Especiais Cíveis e Criminais no âmbito da Justiça Federal (Lei n ${ }^{\circ}$ 10.259/2001), completa vinte anos da sua aprovação, seis anos depois da aprovação da lei que criou, em âmbito estadual, os Juizados Especiais Criminais (JECrims) e Cíveis (JECs), pela Lei no 9.099 de 1995.

Desde 2002, ano em que de fato começou a implementação dos primeiros juizados especiais federais (JEFs) no Brasil, eles chamaram a atenção de vários cientistas sociais que buscaram entender o funcionamento desse ainda embrionário microssistema judiciário (AMORIM, 2006), ensejando a produção de trabalhos empíricos, ainda poucos, mas em notável aumento nos últimos anos. Isso partiu de pesquisas realizadas no Rio de Janeiro (AMORIM, 2006, 2008), atravessou outras mais amplas em distintos Estados da Federação (IPEA, 2012; IGREJA; RAMPIN, 2012) e desdobrou-se em investigações mais recentes (NERI; GARCIA, 2017; ANGELO; CARDOSO DE OLIVEIRA, 2021).

Partindo de tal conjuntura, este artigo visa atualizar a pesquisa qualitativa realizada por meio de trabalho de campo anteriormente feita e já publicada (AMORIM, 2006) ${ }^{3}$, dialogando com dados quantitativos sobre tais observações em campo, mas nunca publicados ${ }^{4}$, além de dialogar com trabalhos atuais e suas conclusões a partir da empiria.

Desta forma, a análise quantitativa objetivou complementar resultados de pesquisa qualitativa realizada entre 2004 e 2006 sobre conflitos nos JECs Federais. Os dados quantitativos foram inicialmente obtidos em dois juizados federais, mediante autorização dos respectivos magistrados titulares de tais varas. Porém, o desembargador responsável pela Coordenadoria dos Juizados Federais da $2^{\mathrm{a}}$ Região Federal não permitiu o prosseguimento da pesquisa, sem autorização expressa do tribunal. Realizado o procedimento burocrático

\footnotetext{
${ }^{3}$ Assim, o objetivo deste artigo não é a pura republicação de trabalho anterior, mas agregar dados quantitativos, e suas análises, a esse escrito, anteriormente não realizado. Versão já publicada deste trabalho, mas sem os dados e as análises quantitativas, pode ser conferida em AMORIM, Maria Stella Faria de. Juizados Especiais na região metropolitana do Rio de Janeiro. Revista Seção Judiciária do Rio de Janeiro - SJRJ, n. 17, p. 107-131, 2006.

${ }^{4}$ Os dados foram apresentados na VIII Reunión de Antropologia del Mercosur, 2009, em Buenos Aires, no GT Diversidad y Poder en America Latina.
} 
requerido, a pesquisa recebeu autorização do tribunal e recomeçou quatro meses após ser interrompida, abandonando os dados inicialmente colhidos com autorização dos magistrados.

Finalmente, foram disponibilizados doze mil processos findos nos juizados federais cíveis no ano de 2007. Após analisada a representatividade dos processos autorizados para consulta, foi calculada uma amostra aleatória de duzentos e oitenta processos originados de três juizados federais cíveis do Rio de Janeiro e um de São Gonçalo, o que permitiu traçar o perfil dos conflitos predominantes, assim como o perfil dos demandantes nesses juizados.

A pesquisa quantitativa confirmou dados já obtidos em trabalho de campo, baseado na observação direta de audiências e em entrevistas abertas com partes e com operadores atuantes nos JEFs, assim como permitiu a apreciação interna e sistemática dos processos, impossível de ser captada qualitativamente.

Para obter respostas sobre o funcionamento dos juizados federais, foram consultadas as principais peças do processo: o pedido expresso na petição inicial, a contestação, a sentença do magistrado, a decisão do recurso (no caso de ter havido um recurso), o tempo de tramitação do processo no juizado, além de outros dados sobre os demandantes. A pesquisa considerou a amostra representativa das situações que ocorriam nos juizados, sendo constatada uma sensível recorrência nos conflitos levados aos juizados federais, o que já havia sido observado na pesquisa qualitativa. A distribuição dos processos pesquisados na amostra foi feita da seguinte maneira: oitenta questionários para o JEF de São Gonçalo e duzentos questionários para o JEF da capital do RJ. Os principais conflitos apontaram duas agências federais como as principais rés nos juizados federais, nas suas competências cíveis e previdenciárias: o Instituto Nacional do Seguro Social (INSS) e a Caixa Econômica Federal (CEF).

A escolha dos JEFs, nas competências cíveis e previdenciárias, como objeto de pesquisa se dá por uma das questões tradicionalmente mais salientadas entre o direito e a sociedade no Brasil, que é a desvinculação entre a cultura especializada dos operadores jurídicos e a cultura cívica dos cidadãos que acolhem a prestação jurisdicional nos tribunais. Cooperam para tal separação certas características do direito brasileiro como, por exemplo, a falta de literalidade das leis e a debilidade de consenso sobre as decisões judiciais para casos semelhantes. Assim, não basta que a lei esteja escrita, ela necessita ser interpretada, o que significa que mesmo pessoas com alto nível de educação não estariam certas sobre o que precisamente significa o que nela está escrito. Da mesma forma, as 
interpretações variam bastante, pois os doutrinadores podem exprimir entendimentos distintos sobre uma mesma lei, o que é identificado na categoria nativa "corrente doutrinária”. Além disso, os magistrados detêm livre convencimento ${ }^{5}$ sobre o que consta dos autos processuais, derivando, tanto deste aspecto, como dos anteriores, distribuição desigual da justiça. Isso é verificado nos casos em que os jurisdicionados enfrentam conflitos de natureza similar e recebem decisões diferentes ou até opostas. Entendimentos dissonantes na doutrina sobre um mesmo texto legal levam o magistrado a encarar dois níveis de conflito para decidir: primeiro, ele necessita desvendar conflitos de interpretação legal, para depois sentenciar sobre o conflito material em apreço.

Tal situação sugere a presença predominante da lógica do contraditório em todo o direito brasileiro (LIMA K., 2010, p. 29), compreendendo tanto a dimensão chamada teórica, como a doutrinária e a prática. Portanto, a lógica do contraditório vai para além da fase processual garantida às partes, o que atravanca firmar consensos sobre os valores sempre embrulhados nas considerações judiciais e que também estão presentes na sociedade ${ }^{6}$. Neste sentido, a lógica do contraditório é um tipo de lógica interminável, em que a argumentação dos participantes do cenário comunicativo só é interrompida por uma autoridade judicial. Nesta tradição seguida pela justiça brasileira, sem a intervenção de um tertius para cessar o contraditório, ele poderia prosseguir até o infinito. De forma semelhante, entre operadores e doutrinadores, o papel da autoridade, imaginada como independente e livre para decidir, põe fim ou descontinua a contradita, sem que seja socializado entre os interlocutores algum consenso judicial sob a matéria em monta. $\mathrm{O}$ contraditório difere de outras lógicas abertas, em que a argumentação visa obter consenso entre os participantes da questão, sejam eles autoridades ou não. Nessas circunstâncias, os interesses das partes em conflito tendem a ficar isolados da prestação jurisdicional, assim como elas próprias, protagonistas principais, ficam despersonalizadas e passam a ter

\footnotetext{
${ }^{5} \mathrm{O}$ artigo 371 do atual Código de Processo Civil, de 2015, dispõe que “o juiz apreciará a prova constante dos autos, independentemente do sujeito que a tiver promovido, e indicará na decisão as razões da formação de seu convencimento". Porém, isso se distingue do princípio do livre convencimento motivado, ainda fortemente presente nas decisões dos juízes, a exemplo do que mostra a pesquisa de Ulisses Fialho Simas em: SIMAS, Ulisses Fialho. O livre convencimento motivado dos juízes no novo código de processo civil. Dissertação (Mestrado em Direito) - Universidade Veiga de Almeida, 2020.

${ }^{6}$ GARAPON, Antoine. O juiz e a democracia. Rio de Janeiro: Editora Revan, 1999. Muitos desses valores estão expressos na Constituição brasileira e são apenas simbolicamente usados, sem que sua validade se atualize ou que estejam "normalizados" nas relações sociais. Entre os autores que postulam as lógicas comunicativas abertas estão, por exemplo, Chaim Perelman, Jürgen Habermas, Karl-Otto Apel, entre outros, que privilegiam a mediação, a conciliação e a negociação de interesses, de modo a consensualisar posições ou decisões entre partes com valores ou com interesses distintos.
} 
contato indireto, via seus representantes contratados livremente ou dispostos pelo Estado nos processos judiciais que lhes dizem respeito.

Diante dessas questões, a escolha dos juizados como cenário privilegiado pela pesquisa deve-se à circunstância de terem eles mais se aproximado da população do que os tribunais comuns, permitindo assim melhor visualizar as relações entre o direito, os tribunais e a sociedade no Brasil. Outra característica que leva a pesquisa a concentrar-se nos juizados é a atualidade e a espontaneidade dos conflitos que a eles são levados pela sociedade. Note-se que, ao serem criados, os juizados não privilegiaram qualquer tipo de conflito em particular. Ao contrário, o critério adotado quanto aos juizados criminais foi o pequeno potencial ofensivo, entendido como curto tempo da pena estabelecida para o delito praticado (inicialmente, até um ano de pena prevista no Código Penal e, atualmente, até dois anos de pena). Quanto aos juizados cíveis, o critério também não destacou nenhum tipo de conflito, apenas fixou o máximo de valores das causas em teto menor do que as encaminhadas à justiça civil comum e a baixa complexidade da causa a ser apreciada.

No entanto, ao entrarem em funcionamento, os juizados passaram a receber, em quantidade expressiva, certos tipos de conflitos sociais cuja natureza não havia sido prevista e que viriam a influenciar o desempenho do modelo legal que lhes foi atribuído. É possível admitir variações quanto à prestação jurisdicional nos juizados, tanto em relação à expressividade numérica do atendimento que prestam à população, quanto à natureza dos conflitos para eles dirigidos em diferentes regiões brasileiras. Primeiro, porque a despeito da legislação comum que os regula, as justiças estaduais detêm liberdade para regulamentar a atuação dos juizados dentro de suas respectivas jurisdições. Segundo, porque, em diferentes regiões do país, os conflitos submetidos aos juizados podem deter natureza e quantitativos distintos. Porém, na Região Metropolitana da capital do Estado do Rio de Janeiro, onde a pesquisa foi realizada, os tipos de conflito predominantemente encaminhados aos juizados apresentam natureza similar à das pesquisas realizadas em outras regiões brasileiras.

Aos juizados estaduais cíveis, a sociedade encaminhou, predominantemente, conflitos em relações de consumo de bens e serviços.

Embora já existisse o Código de Defesa do Consumidor, a proteção por ele concedida foi bastante ampliada com o advento dos juizados cíveis dos estados, visto que qualquer 
cidadão poderia recorrer à justiça, sem maiores custos, para reclamar de contratos de compra de qualquer bem ou serviço que não correspondesse às condições da oferta pelo vendedor no ato da operação realizada no mercado, observados os limites de valores para os bens e serviços reclamados, em conformidade com o prescrito na Lei ${ }^{\circ}{ }^{9}$ 9.099/95.

Aos juizados estaduais criminais, a sociedade respondeu com conflitos nas relações domésticas (predominantemente verificados entre homens e mulheres adultos, casados legalmente ou não) e de vizinhança, a maioria deles tendo como vítimas mulheres e como agressores os homens ${ }^{7}$. Antes da criação desses juizados, tais conflitos eram habitualmente encaminhados para as delegacias policiais e administrados pelos delegados, sendo conhecidos na esfera policial como "feijoadas". Com o advento dos juizados criminais estaduais, passaram a receber tratamento judicial, previsto na Lei ${ }^{\circ}$ 9.099/95, tornandose assim mais amplamente judicializados (VIANNA et al., 1999) na sociedade, sobretudo entre segmentos menos favorecidos da população.

\section{A ATUAÇÃO DOS JUIZADOS ESPECIAIS FEDERAIS: RELAÇÕES CONFLITUOSAS DE PARTICULARES CONTRA O ESTADO}

Os Juizados Federais começaram a atuar a partir de 2002. O artigo 98, parágrafo primeiro, da Constituição Federal de 1988 autorizou a União no Distrito Federal, nos Territórios e nos Estados da Federação a criar juizados especiais. Entretanto, o entendimento concedido a esse artigo foi de que os juizados federais poderiam ser criados apenas no Distrito Federal e nos Territórios. Com a transformação dos antigos Territórios em Estados da Federação brasileira, esse entendimento ficou ainda mais limitado quanto à introdução dos juizados na Justiça Federal. Somente após a aprovação da Emenda Constitucional n 22, de 1999, o Poder Executivo encaminhou ao Congresso Nacional um projeto de lei propondo a ampla

\footnotetext{
${ }^{7}$ Veja-se, por exemplo, as pesquisas de Breno Inácio Silva (2004), Rodrigo Ghiringhelli Azevedo (2000), Ângela Moreira Leite (2003) e Michel Lobo Toledo Lima (2017).

${ }^{8}$ Nas esferas judiciais, os conflitos encaminhados aos juizados, tanto cíveis como criminais, também são vistos como "bagatelas", ou seja, como pouco relevantes, se comparados aos que se apresentam na Justiça Comum. Veja, por exemplo, em SOUZA, Érika Giuliane Andrade. Formas de Administração de Conflitos no Espaço Público: Casos de feijoada da polícia da cidade do Rio de Janeiro. Trabalho apresentado na 26a Reunião Brasileira de Antropologia, realizada entre os dias 01 e 04 de junho de 2007, Porto Seguro, Bahia, Brasil.
} 
criação dos juizados no âmbito da Justiça Federal. O projeto, diga-se, de iniciativa do Superior Tribunal de Justiça, recebera apoio da magistratura e teria " [...] envolvido toda a classe jurídica do País, especialmente os Juízes Federais, que, através da Associação dos Juízes Federais do Brasil (AJUFE), se mobilizou para apresentar suas sugestões a respeito" (ALVIM, 2002, p. VII).

Inspirados na Lei n 9.099/95, foram então criados os Juizados Especiais da Justiça Federal brasileira, com a aprovação da Lei n 10.259 em 12 de julho de 2001. Já no curso da aprovação do projeto de lei surgiram dificuldades relativas aos juizados criminais federais, porque na grande maioria dos crimes contra a União estabelecem-se penas superiores a 1 (um) ano, limite este fixado para o pequeno potencial ofensivo contemplado na Lei $n^{\circ}$ 9.099/95 para os juizados criminais estaduais. Assim sendo, este limite foi estendido para os crimes com pena prevista até dois anos na Lei $\mathrm{n}^{\circ} 10.259 / 01$ e, por força de uniformização de legislação, passou a ser adotado nos juizados criminais dos estados, regidos pela Lei $n^{\circ}$ 9.099/95. A alteração não trouxe modificações expressivas, prevalecendo nestes juizados a presença predominante dos conflitos domésticos e entre partes mutuamente conhecidas. Também a ampliação para delitos com penas previstas até dois anos de detenção não aumentou a demanda nos juizados criminais federais, que se manteve relativamente baixa. Os conflitos levados a esses juizados, na maioria, caracterizam-se por queixas sobre abuso de autoridade, desacato à autoridade na pessoa de servidores públicos federais e, raramente, afastam-se desses padrões. Quando isso acontece, o caso ganha notoriedade, como aconteceu com uma briga, seguida de agressão física, entre dois particulares, passageiros de um avião da Varig trafegando em espaço aéreo sob jurisdição federal.

Já nos juizados cíveis federais, a demanda é muito alta desde que estes microssistemas entraram em funcionamento. Reprimida de longa data, a demanda logo explodiu nesses juizados, que encerravam esperanças inovadoras nutridas por magistrados federais. Tais magistrados participaram de gestões destinadas à elaboração da Lei $n^{\circ}$ 10.259/01. A este respeito, descreveu um deles:

Vejo o juizado especial federal como uma solução diversa da Justiça tradicional, feita nos moldes do Código de Processo Civil, ainda apegado ao formalismo, e, sobretudo, uma excelente oportunidade para democratizarmos o processo, tratando as partes paritariamente, sem qualquer privilégio para os entes federais. 
E, prosseguindo, o mesmo magistrado diz: "Penso que se não acabarmos com os privilégios que são reconhecidos aos entes públicos nesse País, esse juizado especial que se pretende criar será tão emperrado como é a Justiça tradicional [...]”. Em seguida conclama seus pares: "Vamos utilizar essa 'cova rasa' para sepultar esses odiosos e injustificáveis privilégios com que nosso ordenamento jurídico ainda brinda a União Federal e suas autarquias e fundações" (ALVIM, 2002, p. XVII-VIII).

As esperanças dos magistrados federais diminuíram quando os juizados começaram a funcionar, pois para eles a sociedade respondeu com uma invasão de conflitos, majoritariamente contra agências públicas como o Instituto Nacional de Seguro Social e a Caixa Econômica Federal, ficando a primazia do lugar de réu com o INSS, seguido da CEF. Embora os conflitos envolvam ações de particulares contra o Estado, eles podem ser tipificados de maneira distinta.

A maioria dos conflitos envolve principalmente reclamações sobre direitos sociais não atendidos. Em segundo lugar, aparecem demandas sobre correção do FGTS e de poupanças, ambos com o mesmo índice de correção monetária. São todos conflitos do cidadão contra o Estado, ou seja, conflitos contra a União Federal. A principal causa desses conflitos decorre do mau atendimento oferecido pelo INSS e pela CEF a seus usuários. Conforme a pesquisa qualitativa apontou, o mau atendimento gera conflito não administrado por essas agências e é levado pelos cidadãos aos Juizados da Justiça Federal, onde recebem tratamento judicial, satisfazendo o pedido inicial do autor em tempo relativamente breve, como está assinalado adiante no respectivo gráfico.

O Gráfico 1 demonstra a frequência dos conflitos mais recorrentes nos JEFs. Os menos recorrentes aparecem com percentuais baixos na pesquisa, mas sempre estariam abaixo dos altos percentuais alcançados pelos conflitos contra o INSS e a CEF como réus, conforme já indicara a pesquisa qualitativa. 


\section{Gráfico 1 - Réu no Processo}

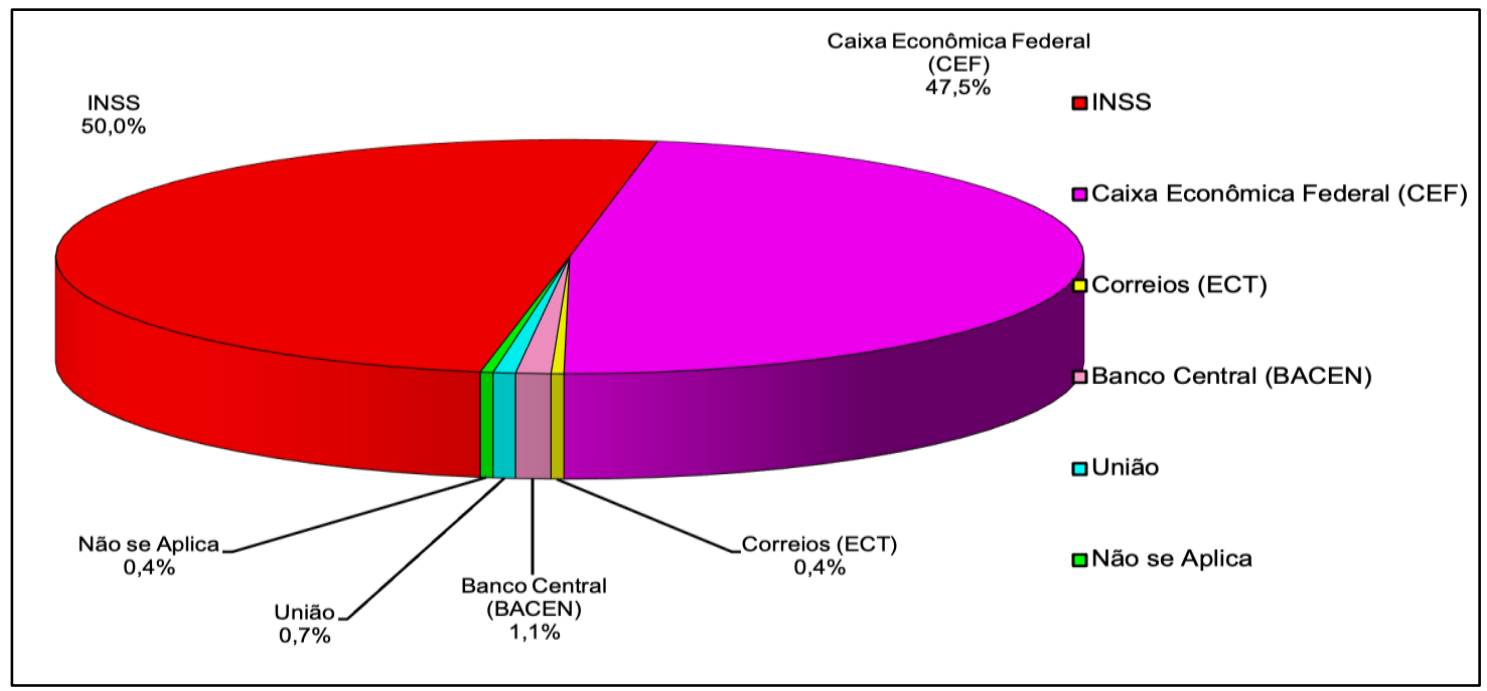

Fonte: autores

O Gráfico 2 mostra que foram encontrados nove tipos de demandas. A maioria delas reclama por direitos legislados. Os réus mais costumeiros são o $\operatorname{INSS}^{9} \operatorname{com} 51 \%$ de ações e a CEF com 46,4 \%, totalizando 97,4\% de ações movidas por pessoas físicas, desprezadas outras ações $(2,6 \%)$. As demandas identificadas como direitos sociais atingem 67,1\% nos juizados estudados.

\footnotetext{
${ }^{9}$ Muito do que foi verificado entre 2006 e 2007 ainda se observa e confirma atualmente, no que tange às características das demandas, dos processos e de como se dá a administração de conflitos nos JEFs. Segundo o relatório Justiça em Números do Conselho Nacional de Justiça de 2020, por exemplo, destaca-se na Justiça Federal o elevado quantitativo de processos de direito previdenciário nos Juizados Especiais Federais e nas Turmas Recursais. Disponível em: <https://www.cnj.jus.br/wp-content/uploads/2020/08/WEB-V3-Justi\%C3\%A7a-emN\%C3\%BAmeros-2020-atualizado-em-25-08-2020.pdf >. Acesso em: 30 mar. 2021.
} 
Gráfico 2 - Tipos de Demandas no JEF

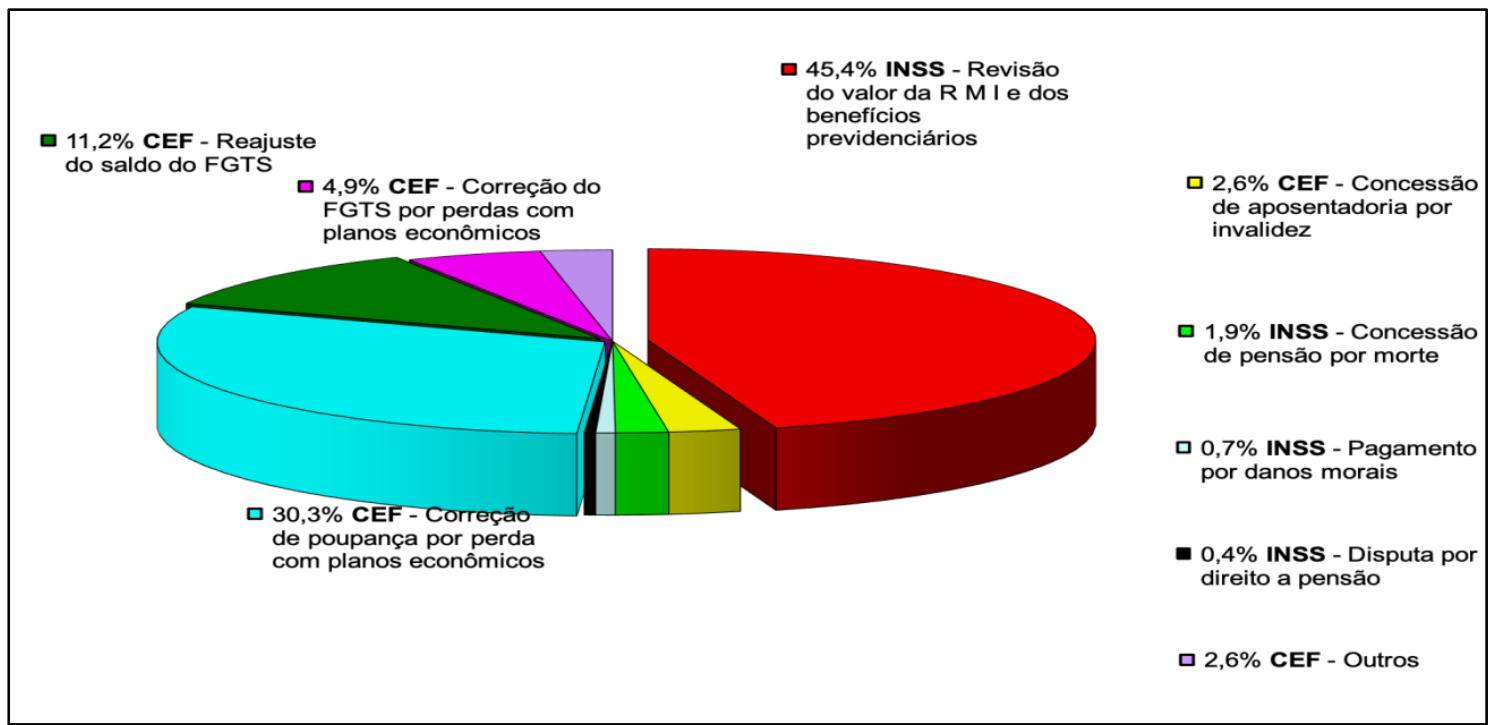

Fonte: Autores.

Os conflitos com o INSS são caracterizados por ações que reclamam pagamentos de benefícios sociais, como aposentadoria, pensões de viúvas, companheiras que passaram por separação conjugal ou mulheres que enviuvaram com a morte de seus companheiros e requerem pensões para seus filhos menores. São ainda objeto de ações contra o INSS reclamações contra maus atendimentos na rede hospitalar mantida pelo governo federal, dificuldade de acesso a consultas médicas, a internações hospitalares e a medicamentos em estabelecimentos federais. Enfim, são direitos sociais previstos na Constituição, em grande parte legislados, mas que não estão diretamente disponíveis para os cidadãos brasileiros, sobretudo para os integrantes de camadas sociais economicamente desfavorecidas, justamente as que mais recorrem aos juizados.

Para obter benefícios previdenciários do INSS, há de se lançar mão do direito de ação civil contra o Estado, pois estes direitos sociais não estão diretamente ao alcance da população. Basta ver o expressivo número de cidadãos que buscam os juizados para ter acesso aos direitos sociais em tela. Como os juizados admitem reclamações por dano moral, já foram concedidas indenizações por dano moral praticado pelo Estado - o que, diga-se, é muito raro acontecer - a alguns reclamantes cujo benefício havia sido requerido há mais de uma década e só liberado recentemente. Em períodos que ocorrem decisões concedendo correção de remuneração aos servidores ou relativa ao FGTS, grande quantidade de ações contra a União é encaminhada aos 
juizados federais. Nesses casos, também a concessão da correção não é produzida de imediato, ensejando a promoção pelo interessado de ação civil contra o Estado.

Já os conflitos com a CEF são de natureza diferente dos anteriormente mencionados e referem-se ao mau atendimento recebido pelo cidadão nessa agência governamental, dos quais resultam prejuízos ao cliente. A CEF é uma empresa de caráter misto. Desfruta de regime jurídico público quando concede apoio financeiro a programas sociais do governo e dispõe de regime jurídico privado, como qualquer instituição financeira particular, quando presta serviços bancários a seus clientes. Como um dos maiores escoadouros de pagamentos de benefícios previdenciários, a CEF conta entre seus clientes com grande número de beneficiários da Previdência Social. Justamente em relação as suas atividades bancárias, ela se torna visada como uma das principais rés nos juizados federais cíveis.

Tais conflitos poderiam ser vistos como regulados pelo Código de Defesa do Consumidor, porém os magistrados federais tenderam a evitar essa caracterização, em vista de o assunto ser objeto de controvérsia, só recentemente decidida pelo STF, que estabeleceu serem os serviços bancários objeto de apreciação judicial e amparados pelo Código de Defesa do Consumidor. A CEF atua como qualquer instituição financeira privada, e muitas das reclamações judiciais apresentadas contra ela são análogas às encaminhadas contra bancos privados nos juizados da justiça estadual, onde a tendência de ampará-las pelo Código de Defesa do Consumidor já era maior e hoje foi estabelecida por decisão do STF.

A CEF instalou um sistema de atendimento segmentado, considerado pelos seus gerentes como "moderno" e "avançado" no setor de serviços bancários. O sistema obedece a critérios quantitativos diferenciados entre os valores de depósito dos clientes. Estudo realizado nas agências localizadas em bairros da Zona Sul e da Tijuca revela que, na área investigada, o atendimento para clientes que dispõem de depósitos até 5 mil reais - justamente onde está grande número de beneficiários da previdência, incluindo vasta quantidade de "desbancarizados"10 - é de um gerente para 13 mil pessoas ${ }^{11}$. Assim, nos juizados do Centro do Rio de Janeiro, são frequentes as ações relativas à perda de cartões e ao seu uso por terceiros para movimentações indevidas em contas; desaparecimento de valores depositados em contas;

\footnotetext{
10 "Desbancarizados" são aposentados ou pensionistas que recebem benefícios regulares no caixa das agências, mediante comprovantes nominais, sem possuírem conta bancária.

${ }^{11}$ Mais detalhes em: CASTRO, Leopoldo Orsini de. O projeto de segmentação na Caixa Econômica Federal: a percepção do gerente. Dissertação de Mestrado em Administração de Empresas. PUC-RJ, 2004.
} 
mudança de pagamento de benefício da agência na qual originalmente a remuneração era recebida para outra agência, sem aviso ao cliente, entre outras questões, que poderiam dispensar o uso da máquina judiciária, caso a CEF oferecesse atendimento diferenciado mais condizente com as características e com o quantitativo expresso na feição dos clientes que estão na base de sua pirâmide de atendimento segmentado.

Outro tipo de conflito está presente no cenário investigado que, embora não ocorra na esfera judicial, a afeta de maneira significativa. Relativamente ao acesso da população a benefícios previdenciários - ou seja, a direitos sociais -, podem ser identificados o que denominamos de "conflitos intraestatais" por ocorrerem entre entidades estatais. Trata-se de conflito oculto para a maioria dos atores presentes no cenário relativo à administração dos conflitos judiciais estudados, tais como os que se verificam entre o INSS e a CEF, e que se desdobram entre estas agências governamentais e o Poder Judiciário. É comum o INSS autorizar o pagamento do benefício, e a CEF não pagá-lo, alegando haver problemas na identificação do beneficiário, o que enseja a entrada de ações no juizado federal.

O atendimento no INSS é bastante lento e envolve várias idas do interessado a esta agência para acompanhar o requerimento de solicitação do benefício. Se este requerimento não for atendido, o cidadão dirige sua reivindicação aos juizados. Esposas legítimas e companheiras costumam enfrentar dificuldades para ter acesso a benefícios para si e para filhos menores tidos com o falecido. Quando o morto não deixou esclarecida sua relação conjugal com mulheres e com filhos tidos durante a relação mantida com elas, a concessão do benefício pode ser negada ou postergada, ensejando ações judiciais para recebê-lo. Às vezes, o benefício é autorizado para a primeira mulher a reivindicá-lo e se torna muito complicado incluir outras pretensas beneficiárias, sendo difícil rever a concessão primária na esfera administrativa, o que também leva a acionar a justiça para resolver a questão. Benefícios decorrentes de aposentadoria, quando demoram a ser liberados, igualmente resultam em ações nos juizados.

Para os funcionários do INSS, muitas idas do requerente a essa agência prestadora de serviços públicos decorrem de falta de documentação a ser apresentada pelo pretendente ao benefício, o que constitui motivo decisivo para a agência não o conceder. No entanto, do ponto de vista do requerente, a agência estatal o trata sem consideração, gerando nele o sentimento de ofensa pelo menosprezo a ele endereçado. 
Entrevistas realizadas com funcionários responsáveis pelas ações em que a CEF é ré nos juizados mostram que, para os funcionários, é necessário cumprir exigências formais, mesmo que elas venham a retardar o acesso do cidadão a seu direito, apesar de o benefício lhe ter sido concedido pelo INSS. A principal restrição apontada na liberação de pagamentos foram dúvidas acerca da documentação relativa à identificação do beneficiário, em vista de seus documentos apresentarem manchas, rasuras e outros sinais que comprometeriam sua clara legibilidade. No entanto, a mesma documentação é utilizada para interpor ação nos juizados. A este respeito, declarou um funcionário:

A Caixa não pode pagar os benefícios, porque tem a obrigação de proteger o patrimônio da União. Dinheiro da Caixa é dinheiro público, do povo e não pode ser liberado de qualquer jeito, nem para qualquer um... Mas, se a Justiça mandar pagar, a Caixa paga...

E, em prosseguimento, afirmou:

A Caixa só não paga quando existe dúvida sobre a identificação do beneficiado [...]. Mas, se existe um mandado judicial, a responsabilidade pelo pagamento é do Poder Judiciário e não da Caixa. Logo, a Caixa cumpre a ordem judicial e não se responsabiliza pela concessão de benefício sobre o qual teve dúvida. Aí a responsabilidade é da Justiça e a Caixa fica sem responsabilidade pelo pagamento.

Os agentes da CEF e do INSS não admitem haver conflito entre estas agências. Para eles, a explosão da demanda nos juizados nada tem a ver com o mencionado conflito intraestatal, que para eles permanece oculto. Consideram a atuação dessas agências - por eles admitidas como lentas e precárias - independente da recorrência de ações nos juizados. Segundo os funcionários entrevistados, o INSS e a CEF são agências que atuam de maneira independente da dos juizados, entendendo assim que as ações na justiça são "normais". Dissenos um deles que recorrer à justiça é "[...] um direito que o pretendente tem. Tanto assim que as sentenças judiciais são rigorosamente cumpridas".

Do ponto de vista do cidadão que não foi beneficiado na esfera da administração executiva e que obteve o benefício pela via judicial, os juizados são representados como instituições judiciárias de importância especial, pois, sem elas, acham que nunca receberiam o que lhes era devido pelo Estado. Muitos não distinguem o juizado federal e atribuem o efetivo acesso ao benefício à justiça em geral. Percebem que os órgãos do Poder Executivo atuam de maneira oposta ao atendimento de seus interesses, mas não explicitam a natureza do conflito 
aqui denominado de intraestatal. Em suas queixas sobre o atendimento recebido na esfera administrativa, apontam a lentidão e a dificuldade de comunicação entre eles e os atendentes desses órgãos, aspecto que revela a dimensão emocional, porque se sentem ofendidos com o tratamento desconsiderado (CARDOSO DE OLIVEIRA, 2002; LIMA, M., 2018) que lhes foi concedido pelo INSS ou pela CEF.

Ao contrário, na justiça federal já existe opinião quase unânime, de funcionários a juízes, de que o expressivo volume de processos em que o INSS e a CEF são réus resulta de má atuação desses órgãos. Segundo um entrevistado, membro da magistratura federal e atuante nos juizados:

Se o INSS e a Caixa dessem um bom atendimento, diminuiria muito o volume de processos nos Juizados. Muitas situações poderiam ser resolvidas no plano administrativo. Por exemplo, a Caixa tem autorização para fazer pagamentos de valores retidos até $\mathrm{R} \$ 100,00$, mas não faz isso. Então, existem processos em que os autores fazem reclamação para receber $\mathrm{R} \$ 50,00$ e até $\mathrm{R} \$ 30,00$.

Que os juizados federais, assim como os estaduais, contribuíram significativamente para o acesso à justiça é constatação evidente na pesquisa, do mesmo modo que o é na opinião pública. Atualmente, só nos Juizados Federais da $2^{\mathrm{a}}$ Região (integrada pelos Estados do Rio de Janeiro e do Espírito Santo), onde esses microssistemas começaram a atuar em 2002, encontram-se mais de 90 mil ações em trâmite no ano de $2020^{12}$. Tais dados guardam correspondência com a análise estatística de nossa pesquisa nos juizados federais cíveis localizados no prédio da Justiça Federal situado no Rio de Janeiro.

12 Quadro Estatístico dos Juizados Especiais Federais. Disponível em: http://portaldeestatisticas.trf2.gov.br/Pages/QuadroEstatisticoJEF/>. Acesso em: 30 mar. 2021. Já o IPEA, em 2012, verificou que o Instituto Nacional do Seguro Social (INSS) figura como principal réu das ações $(73,1 \%)$, seguido de longe pela Caixa Econômica Federal (CEF), ré em 15,5\% dos casos. Disponível em: <http://repositorio.ipea.gov.br/bitstream/11058/5909/1/BAPI_n03_p78-84_NP_Acesso_Diest_2013-mar.pdf>. Acesso em: 30 mar. 2021. 


\section{CONSTRUINDO DADOS QUANTITATIVOS: DEMANDAS E PERFIL DOS}

\section{AUTORES}

Uma apreciação mais segura das relações entre os juizados e a sociedade necessitaria de que alguns elementos fossem desagregados dentro de qualquer levantamento geral, destacando especificações como, por exemplo, o perfil de quem recorre, se são mais homens ou mulheres, com maior ou menor nível de instrução, a que segmento social pertencem, que tipos de conflitos sociais são predominantemente apreciados nessas cortes, entre outras informações relevantes para se obter uma fotografia mais nítida da relação destes microssistemas com a população.

Os quantitativos disponíveis são provenientes do próprio Judiciário e ficam comprometidos com a perspectiva interna dos operadores nos tribunais, descartando registros relevantes sobre os jurisdicionados que demandam por soluções de problemas que afetam suas vidas cotidianas na sociedade brasileira ${ }^{13}$.

Normalmente as estatísticas disponíveis nos tribunais brasileiros retratam o que chamam de "produtividade dos juízes", que, embora tenham importância internamente para quantificar o exaustivo trabalho dos magistrados, não permitem maiores reflexões sobre a função social dos tribunais na sociedade brasileira, nem mesmo podem assegurar uma quantidade de processos em andamento em certo período, porque mais de um magistrado pode ter atuação no mesmo processo. Por outro lado, ações que foram consideradas improcedentes e não se tornam processos tramitáveis, ou entrarão novamente com pedidos distintos dos que receberam a apreciação de improcedência, também não são conhecidas e podem encerrar limitações de

\footnotetext{
${ }^{13}$ Questão semelhante foi percebida por Michel Lobo ao pesquisar, qualitativa e quantitativamente, os Juizados Especiais Criminais no Rio de Janeiro. O autor notou problemas na forma como os dados eram dispostos pelo Conselho Nacional de Justiça. O primeiro era que os Juizados Especiais Cíveis e Criminais encontravam-se aglomerados em uma mesma categoria, como juizados, sendo analisados em conjunto, não separadamente. $\mathrm{O}$ segundo problema se dava na divisão espacial, em que eram analisados os juizados especiais por Estado, e não por municípios do Brasil, empobrecendo as possibilidades de análise. E a terceira questão se dava nas variáveis escolhidas para análise pelo CNJ, com poucos detalhes de diagnóstico, avaliando apenas o movimento processual, o número de funcionários e o orçamento dos Juizados Cíveis e Criminais em cada estado e por ano, sem considerar os tipos de demanda, as formas de resolução dos conflitos e o perfil das partes conflitantes. Partindo dessa questão, o pesquisador elaborou questionários próprios para coletar dados quantitativos que lhe permitissem detalhar quantitativamente as características das partes, dos conflitos e cruzar dados, assim como analisar o que podia influenciar os desfechos de cada etapa da administração de conflitos do JECrim. Ele utilizou variáveis que constavam nos processos judiciais, a partir das suas observações em campo. Veja mais detalhes da pesquisa em: LIMA, Michel Lobo Toledo. Próximo da Justiça, Distante do Direito: administração de conflitos e demanda de direitos no Juizado Especial Criminal. Autografia: Rio de Janeiro, 2017.
} 
acesso à justiça ${ }^{14}$. Deste modo, torna-se praticamente impossível determinar um quantum de exatidão confiável a respeito dos processos que tramitam nos juizados, mesmo em período curto. No entanto, as estimativas de que são em grande quantidade parecem não contradizer a realidade, ainda meio ofuscada a este respeito.

Partindo dessas questões, criamos e organizamos um banco de dados a partir das observações em campo. Os Gráficos 3 e 4, a seguir, apontam a maioria de homens como autores dos processos nos JEFs, embora com certo equilíbrio quanto à distribuição do sexo dos autores, com ligeira prevalência de homens (58\% contra $42 \%$ de mulheres). Já em relação ao estado civil dos autores, a maioria dos demandantes (homens e mulheres) é casado (49\%), enquanto que $22 \%$ são viúvos(as), $19 \%$ são solteiros(as), $5 \%$ são separados(as) ou divorciados(as) ou desquitados(as), e, por fim, em 5\% dos casos não foi possível obter tais informações.

Gráfico 3 - Gênero do Autor do Processo

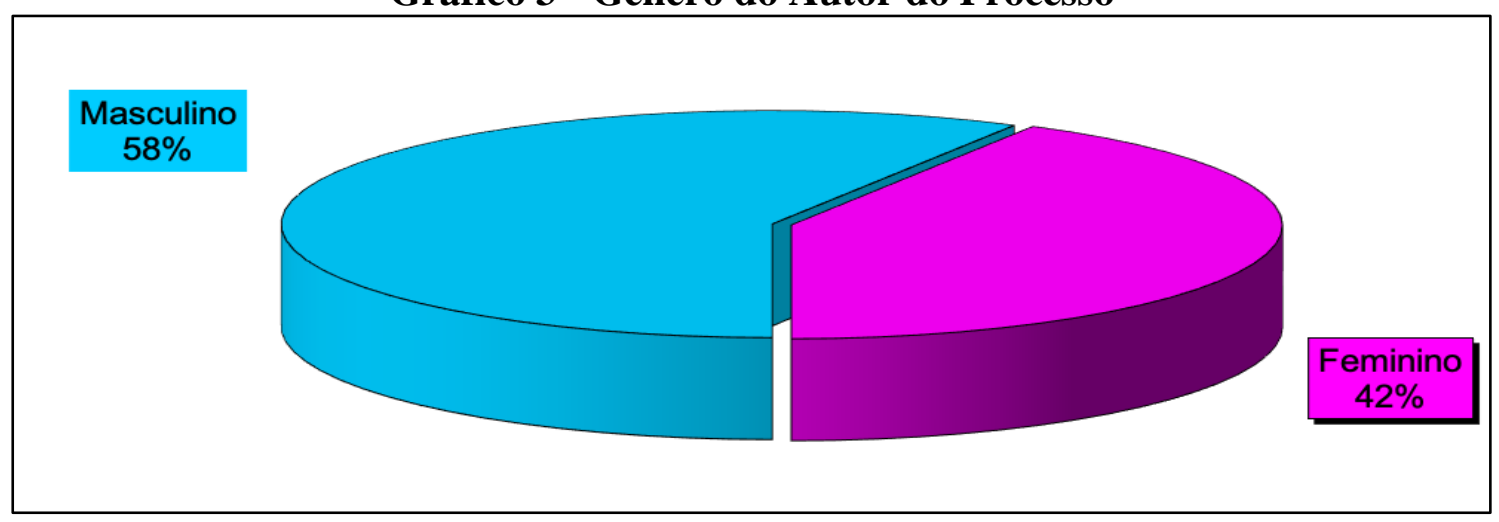

Fonte: Autores.

14 Segundo levantamento do IPEA já mencionado nesse trabalho, em 2012, chama atenção a distribuição (des)equilibrada entre os casos de procedência (integral e parcial), de um lado - 32,4\%, e os de improcedência, de outro $-29,3 \%$. 
Gráfico 4 - Estado Civil da Parte Autora do Processo

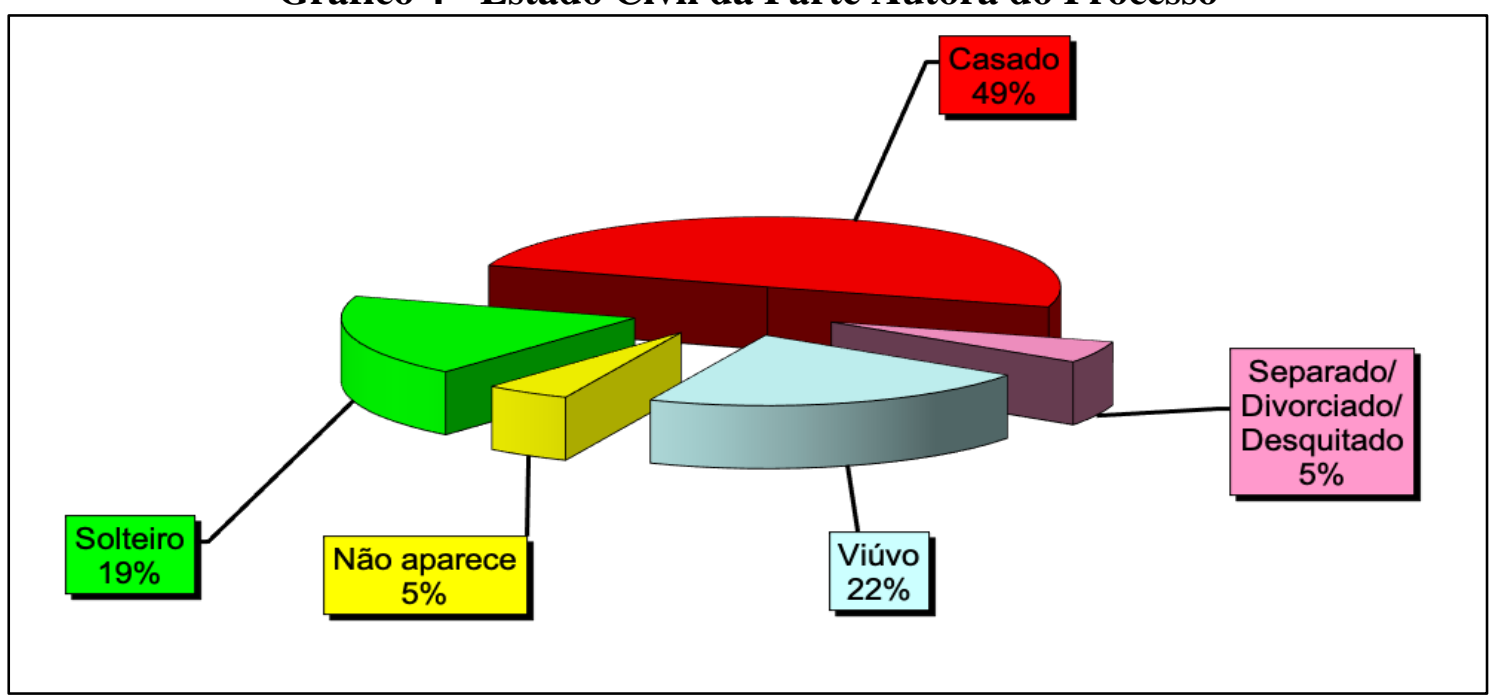

Fonte: Autores.

Em relação à idade, disposta no Gráfico 5, há predominância de demandantes a partir dos 65 anos que equivale a 55\% dos casos; $26 \%$ dos casos estão na faixa etária entre 51 e 65 anos. Somado a isso, há a ocupação das partes autoras (Gráfico 6), predominando os aposentados e os pensionistas, indo ao encontro aos dados sobre a alta demanda previdenciária nesse campo e evidenciando a urgência na apreciação judicial desses casos que, em sua maioria, se referem às necessidades de públicos específicos, como idosos, enfermos e até pessoas com necessidades especiais. Tais características reforçam as observações em campo de que os juizados federais são uma importante forma de acesso à justiça para cidadãos em situação vulnerável. Por outro lado, tais demandas só chegam ao Judiciário em razão da precariedade dos procedimentos que deveriam ter ocorrido de maneira adequada no âmbito administrativo, seja no INSS, seja na CEF, explicitando que o juizado federal é um importante local de administração de conflitos. 
Gráfico 5 - Faixa Etária dos Autores

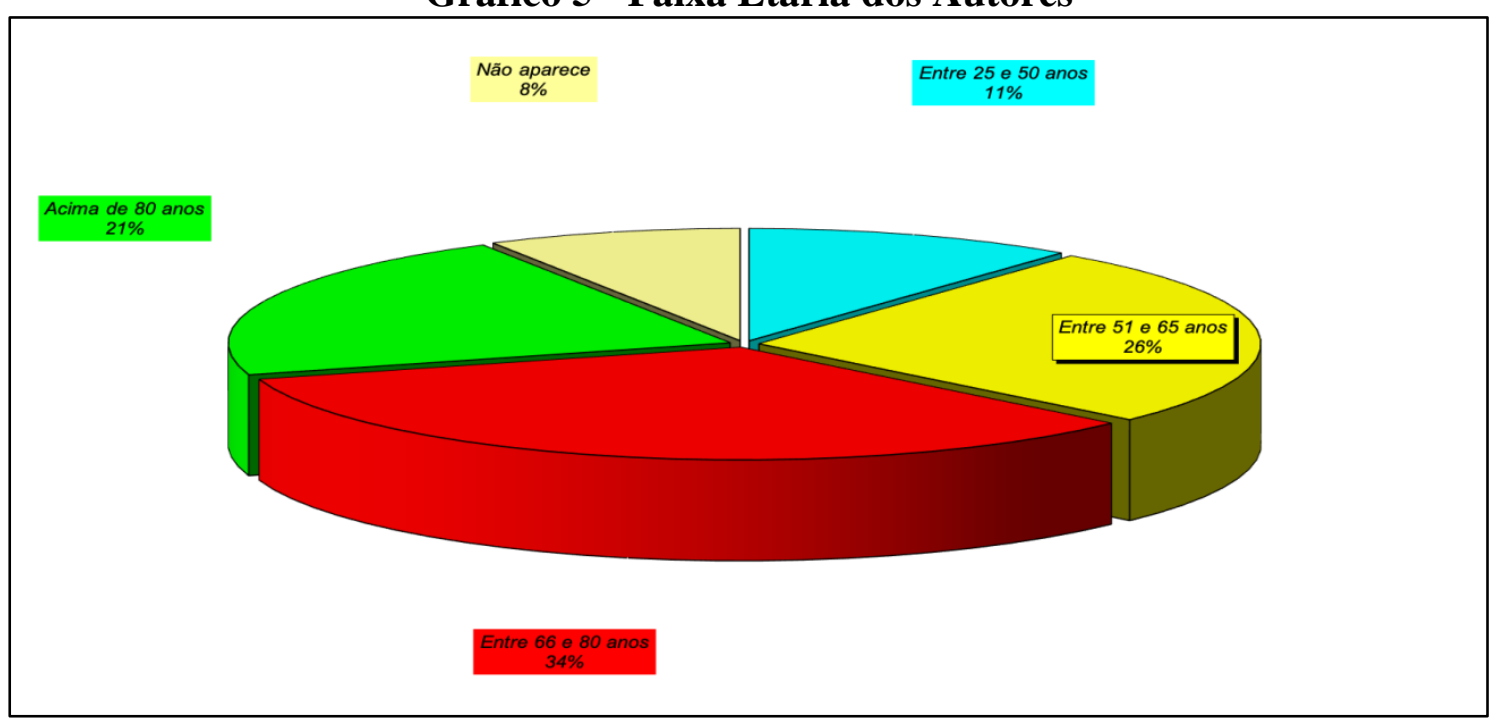

Fonte: Autores.

\section{Gráfico 6 - Ocupação do Autor do Processo}

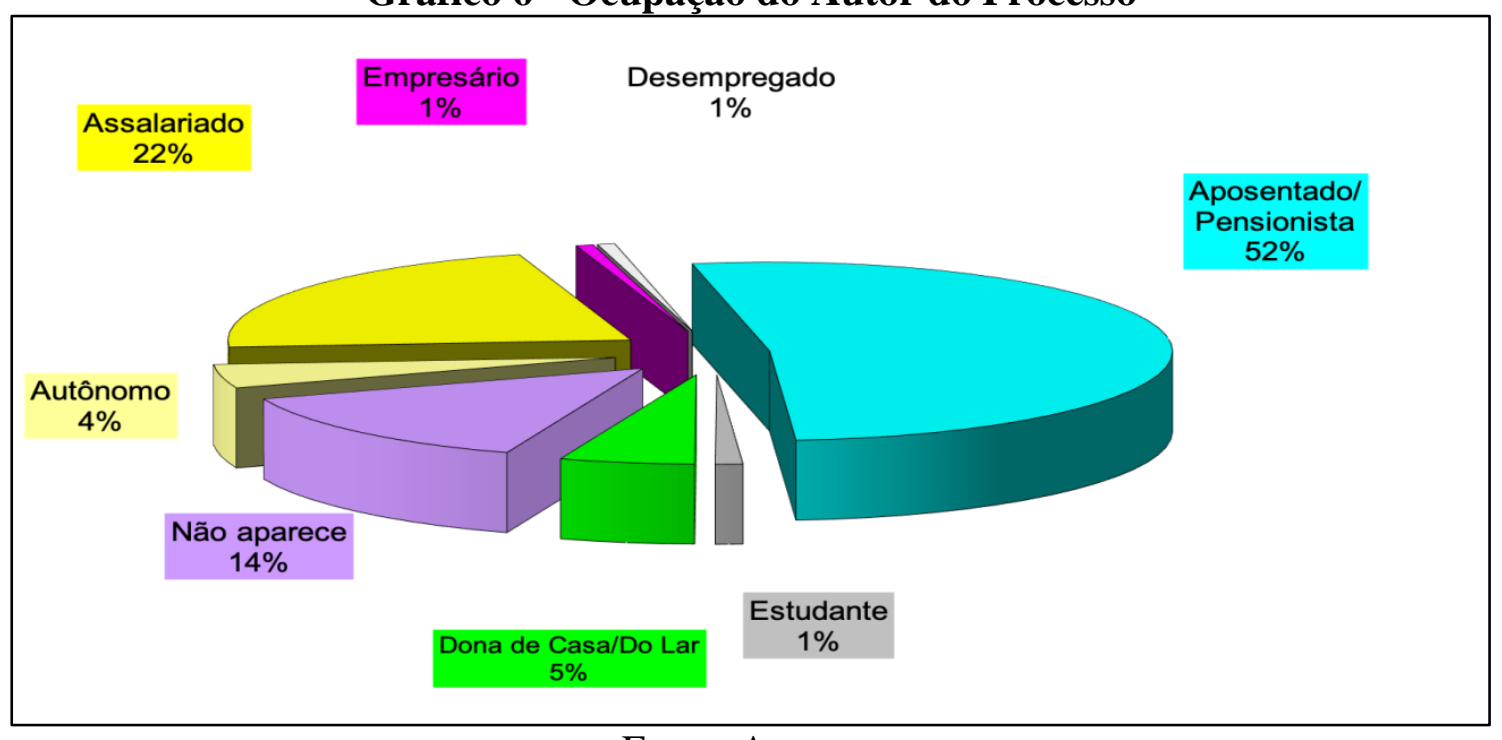

Fonte: Autores.

Assim, outro ponto importante a se analisar é a celeridade desses processos, não como a finalidade principal, mas como uma forma para o efetivo exercício dos direitos reivindicados diante da justiça, buscando garantir uma prestação jurisdicional adequada e o reconhecimento de direitos, com a devida cautela para as necessidades dos demandantes. Nessa questão, os processos também foram analisados quanto ao seu tempo de tramitação, desde a distribuição até a data em que receberam baixa, após dada a sentença pelo juiz, conforme o Gráfico 7. No caso dos juizados investigados, a média do tempo de duração na tramitação do processo foi de 
três meses. Apenas trinta processos foram concluídos até um mês. A pesquisa apontou vinte e quatro meses como o maior tempo de tramitação processual ${ }^{15}$.

\section{Gráfico 7 - Dias Transcorridos até a Baixa}

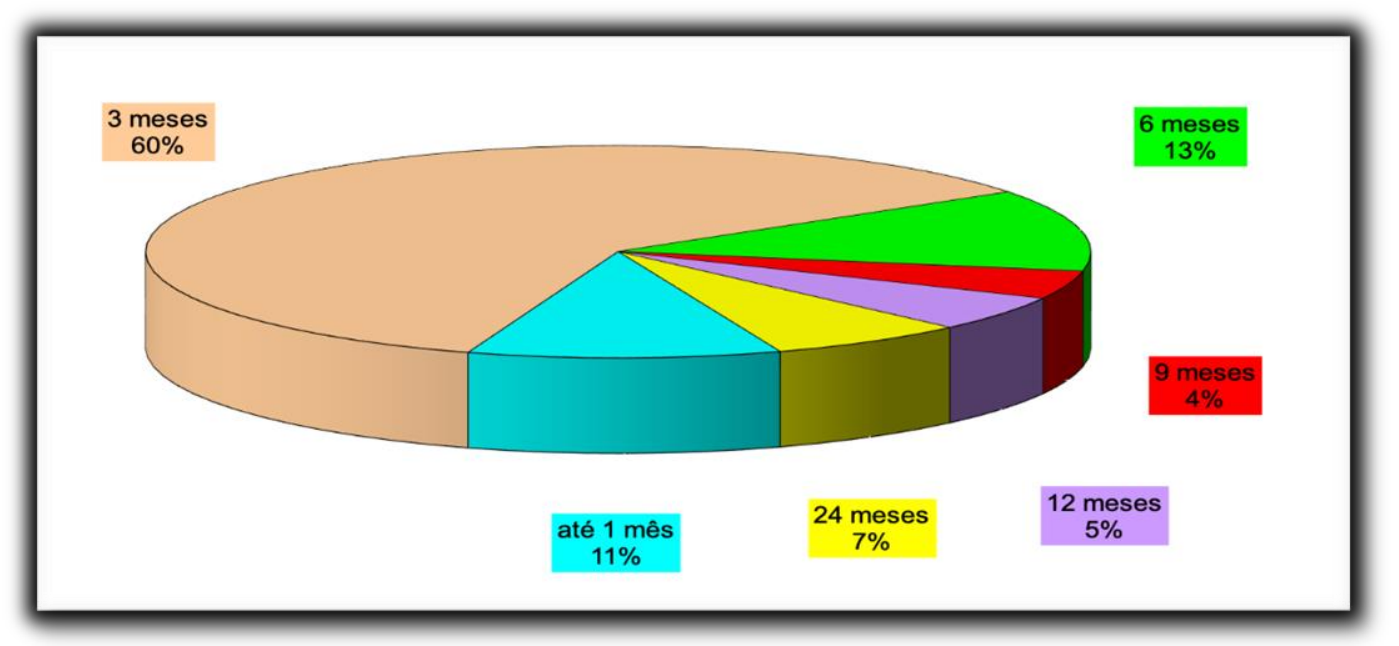

Fonte: Autores.

Da natureza dos conflitos que ocorrem na sociedade, apesar dos nossos esforços em quantificá-los, pouco se sabe com precisão, pois não há uma produção nacional desses dados, mas ainda assim é possível considerá-los razoavelmente tipificados pela recorrência das ações endereçadas aos tribunais que identificamos aqui, conforme assinalam nossos dados de campo e quantitativos. O Conselho da Justiça Federal criou uma tabela, conhecida como TUA (Tabela Única de Assuntos) em que é possível identificar ações previdenciárias, revisões do FGTS, ações de dano material e de dano moral, direitos de servidores públicos. A tabela reproduz a ratio advinda da legislação e não permite identificar a natureza do conflito de interesses entre os particulares e o Estado. Por exemplo, ações previdenciárias envolvem distintas reivindicações dos cidadãos e não seria possível orientar nenhuma política no sentido de implementar intervenções que diminuíssem a lesão de direitos que incentivam as ações previdenciárias contra o Estado, porque a TUA estabelece uma miríade de situações sem distinguir os conflitos agrupados sob um item, o que impede a identificação da natureza do

15 O IPEA, com base numa amostra representativa de autos findos em 2010, calculou o tempo médio de tramitação de uma ação nos juizados especiais federais que foi estimado em um ano, oito meses e quinze dias, ou 624 dias, considerando o intervalo entre o protocolo da petição inicial apresentada pelo jurisdicionado e o encerramento da prestação do serviço às partes mediante arquivamento do processo, ou seja, a baixa dos autos. Disponível em: <https://corteidh.or.cr/tablas/28568.pdf>. Acesso em: 30 mar. 2021. 
conflito para o qual se poderia atentar. Do mesmo modo, prossegue o desconhecimento sobre o tipo de cidadão que mais recorre e o porquê de ele recorrer. Os jurisdicionados tornam-se assim uma ficção abstrata, quando poderiam ser identificados com precisão.

Tais informações seriam relevantes, não apenas para a pesquisa acadêmica, mas para reflexões internas nos próprios tribunais, além de abrirem caminhos seguros para a identificação de aspectos dissonantes, contraditórios e disfuncionais no direito e nas organizações judiciárias brasileiras, que, se visualizados com clareza, poderiam receber as necessárias correções, contribuindo para que a relevante função social dos tribunais ganhasse maior reconhecimento na sociedade.

A corrida da população aos juizados federais, a partir de 2002, quando essas pequenas cortes entraram em funcionamento, foi investigada, e é possível admitir que ela esteja relacionada a alguns fatores.

Em primeiro lugar, há a tradicional demanda reprimida por direitos no Brasil, sobretudo para as camadas menos favorecidas, que, sem condições econômicas de recorrer aos tribunais comuns, encaminharam-se para os juizados especiais, nos quais a prestação jurisdicional é gratuita, e as promessas de rapidez e simplicidade no atendimento, em muitos casos, sem necessidade de advogado, representam atrativos para aqueles que não dispunham (e, ainda hoje, não dispõem) de amparo judicial. Particularmente na justiça federal, na qual a repressão da demanda vinha ocorrendo de longa data, e a opinião pública lhe atribuíra predicados de lentidão e de uma certa "mentalidade fazendária", mais comprometida com os interesses da União do que com os dos cidadãos jurisdicionados ${ }^{16}$, os juizados se ofereceram como importantes organismos atuantes na ruptura com aspectos irremovíveis da tradição judicial, alguns deles ainda presentes na atualidade.

Em segundo lugar, há o mau atendimento atribuído à CEF e ao INSS, enquanto órgãos administrativos do Poder Executivo, também revelador da ausência de socialização dos

\footnotetext{
${ }^{16}$ Embora seja uma boa ferramenta de análise, os registros e dados estatísticos sobre o Judiciário no Brasil geralmente apresentam, pelo menos, três problemas: a carência de uma tradição, acadêmica e institucional, de coleta de dados e de análises estatísticas; o sigilo que as instituições desse campo geralmente fazem, de dados referentes aos seus próprios atos e registros; e a falta de qualidade e a baixa confiabilidade de parte de dados coletados e publicamente divulgados. Para mais detalhes sobre esse debate, veja: LIMA, Michel Lobo Toledo. A Formação do Conhecimento no Campo do Direito e das Ciências Sociais: Questões Teórico-Metodológicas. CONFLUÊNCIAS (NITERÓI), p. 41-63, 2015. Veja também: SOARES, Gláucio Ary Dillon. O Calcanhar Metodológico da Ciência Política no Brasil. Sociologia, Problemas e Práticas, n. 48, 2005, p. 27-52.
} 
servidores quanto aos direitos com que estão ungidos os requerentes de concessão e de pagamento dos benefícios a que fazem jus. Apesar de, costumeiramente, ser atribuída aos requerentes uma "certa ignorância" acerca de seus direitos, não deixam eles de saber como recorrer à justiça para fazê-los valer, conforme demonstra a explosão da demanda nos juizados federais. A respeito do atendimento geralmente prestado por órgãos estatais, um conhecido antropólogo brasileiro, com vasta experiência de vida no exterior, assim escreveu:

\begin{abstract}
No Brasil, existem regras para atender e para pedir. Quem concede o 'dom' é superior e como tal age com vagarosa tolerância e franca condescendência. Nas filas continuamos realizando o ideal escravocrata, segundo o qual o Amo anda grave, compassado e lentamente (pedindo autoritariamente paciência), ao passo que o Escravo 'corre' e espera. A espera é o sintoma de inferioridade social. Fazer-se esperar é uma prerrogativa da importância. O 'chá de cadeira' é a fila do notável. Chegar atrasado é o apanágio do poderoso, aquele cuja presença é estrutural para qualquer começo.

Imobilizando cidadãos definidos como móveis e livres - e eventualmente os matando de direitos que não são atendidos - a fila é, certamente, um dos maiores insultos contra a cidadania moderna ${ }^{17}$.
\end{abstract}

A ausência de uma adequada socialização de servidores sobre os direitos assegurados igualmente a todos os cidadãos "naturaliza" e também contribui para a demora no atendimento, sendo ela objeto de uma série de justificativas que vão desde o mau aparelhamento da agência estatal até seus salários baixos. Tal justificativa, bastante comum entre funcionários do INSS, retorna para uma zona cinzenta e particularmente específica de conflitos interestatais envolvidos em um círculo vicioso - ou melhor, em uma causação circular cumulativa -, pois o Estado, por não atender a direitos legislados para a proteção de seus cidadãos na esfera administrativa, leva-os a recorrer ao próprio Estado (no caso, ao Poder Judiciário) para reclamar pelos seus direitos não atendidos. Forma-se, então, o espantoso volume de processos judiciais, que, talvez, nenhuma justiça deste mundo possa dar conta de atender.

Vislumbra-se, assim, uma espantosa fábrica de processos dentro do Estado, ramificada em seus poderes, pois tanto a fragilidade das garantias cidadãs, como as leis processuais brasileiras parecem se manter dispostas a alimentar a referida produção fabril. E da vasta produção de processos que dela resulta não poderiam os juizados federais dar conta, uma vez que eles próprios também acabam tornando-se depositários desta mesma produção fabril. A

${ }^{17}$ DA MATTA, Roberto. Filas: óbvio ululante e patrimônio nacional. Jornal $O$ Globo, 18.05.2005. 
expressiva demanda por direitos sociais, especialmente os direitos previdenciários, configurada no volume de processos que estes juizados absorvem, acaba por romper com sua proposta de agilidade processual. Para não a perder, os JEFs passaram a informatizar não apenas a informação sobre os processos, mas os próprios processos, no que dispensam as conciliações e, sobretudo, descartam o princípio da oralidade atribuído constitucionalmente aos juizados do Brasil.

\section{3. "PEÇA DE DEFESA PADRÃO": DOIS PESOS DUAS MEDIDAS?}

Após a audiência de conciliação, no JEF, em que não houver acordo, cabe resposta do réu, por meio de contestação, contendo toda sua matéria de defesa, para impugnar, integral ou parcialmente, a demanda proposta pelo autor ${ }^{18}$, podendo, ainda, indicar as provas que pretende produzir. Em geral, essa contestação pode ser aceita até a audiência de instrução e julgamento ${ }^{19}$. O Gráfico 8, a seguir, exibe as principais contestações apresentadas nos juizados investigados. Em $37,5 \%$ dos processos o réu não contestou o pedido do autor, o que quer dizer que coube ao juiz decidir sobre o caso. Em 27,9\% dos processos o pedido do autor foi considerado improcedente. Porém, em 29,3\% a contestação foi feita pela parte ré com o uso da "peça de defesa padrão", que consiste em uma espécie de formulário, utilizado pela parte ré na contestação de todos os processos, independente da natureza da demanda do autor.

\footnotetext{
${ }^{18}$ Artigo 335, Código de Processo Civil.

${ }^{19}$ Enunciado $^{\circ} 10$ do Fórum Nacional dos Juizados Especiais (FONAJE).
} 


\section{Gráfico 8 - Contestações}

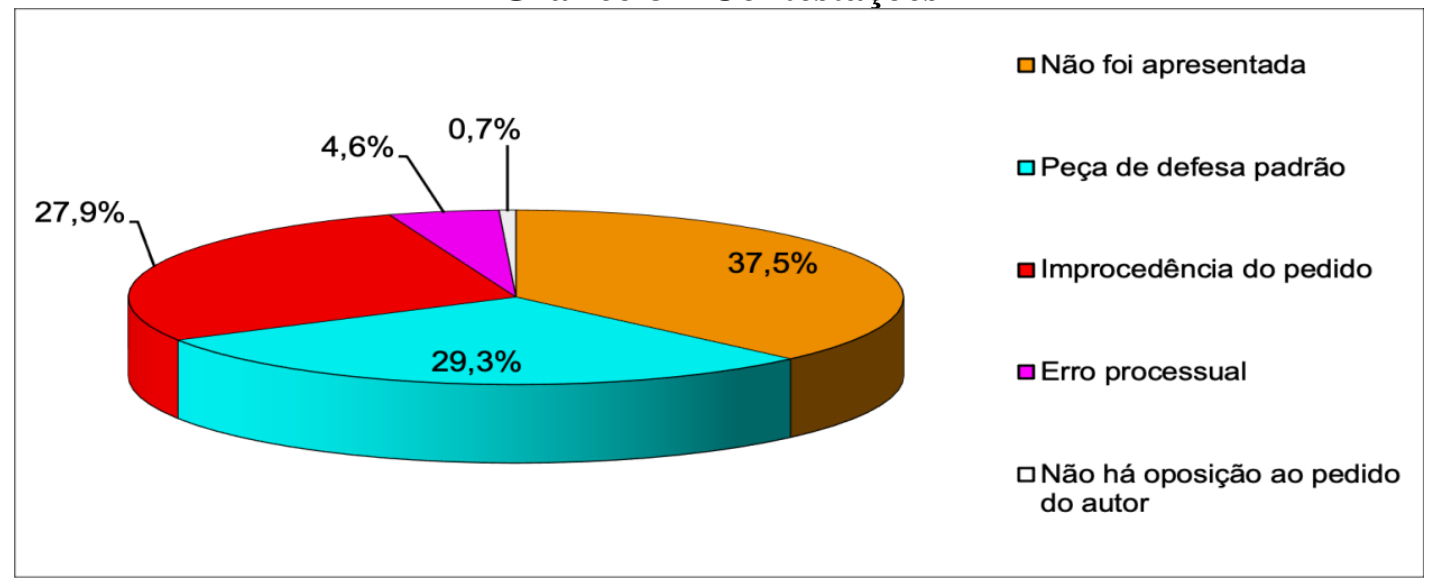

Fonte: Autores.

O Gráfico 9 mostra as motivações das sentenças proferidas. A sentença decorrente de "acordo entre as partes", ou seja, aquela resultante de conciliação, é rara nos Juizados Federais Cíveis, atingindo apenas $1,1 \%$ do total de sentenças proferidas. A maior motivação gerou sentenças de arquivamento do processo, seja por falta de comprovações pelo autor, seja por improcedência da ação.

\section{Gráfico 9 - Sentenças}

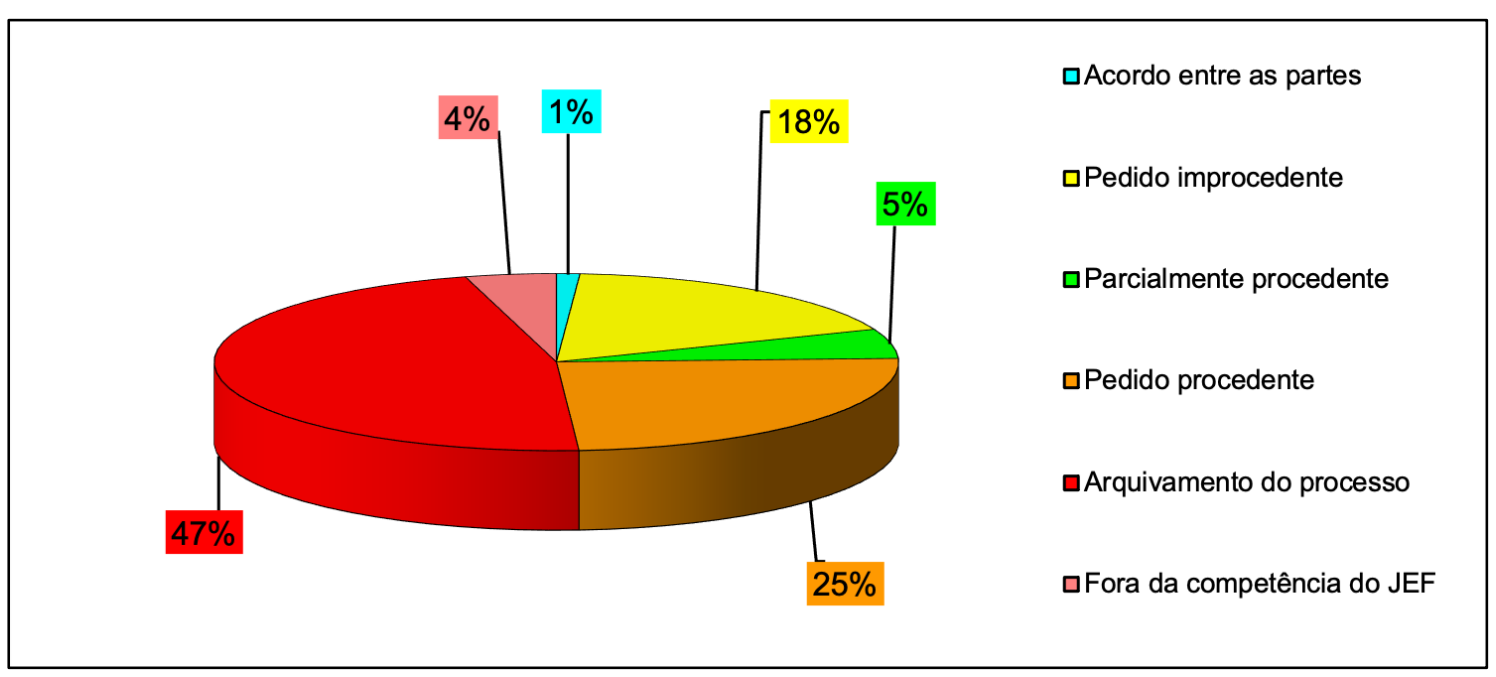

Fonte: Autores. 
Já na Tabela 1, a seguir, são descritas as quantificações das contestações dos réus perante cada decisão tomada e que fora apresentada no Gráfico 8. Nesse cruzamento, observa-se que $37,5 \%$ dos casos não apresentaram contestações pelas partes rés. E mesmo dentro dessa porcentagem de casos em que o réu - INSS ou CEF - não apresentou contestação, 27,5\% teve desfecho por arquivamento, não pleiteando a demanda. A maior surpresa recaiu sobre o papel da "peça de defesa padrão" usada pelo réu (no caso a CEF e o INSS) para contestar os pedidos dos autores; $29,3 \%$ dos réus utilizaram esse tipo de contestação, sendo que 60,3\% dos arquivamentos dos processos se deram por essa contestação. A citada peça motivou a negação, em $1^{\text {a }}$ Instância, de aposentadorias, pensões e correção de benefícios aos reclamantes. Em segundo lugar, há a alegação de ausência de erros como contestação que equivale a 16,10\% dos casos, sendo integralmente acatada em 56,5\% dos casos que adotaram esse tipo de argumento de defesa; e com procedência parcial em $20 \%$ dos casos que apresentaram esse tipo de contestação pela parte ré.

Tabela 1: Contestações dos Réus x Sentenças

\begin{tabular}{|c|c|c|c|c|c|c|c|}
\hline & $\begin{array}{l}\text { Acordo entre } \\
\text { as partes }\end{array}$ & $\begin{array}{c}\text { Pedido } \\
\text { improcedente }\end{array}$ & $\begin{array}{l}\text { Parcialmente } \\
\text { procedente }\end{array}$ & $\begin{array}{l}\text { Pedido } \\
\text { procedente }\end{array}$ & $\begin{array}{l}\text { Arquivamento } \\
\text { do processo }\end{array}$ & $\begin{array}{c}\text { Fora da } \\
\text { competência } \\
\text { do JEF }\end{array}$ & Total \\
\hline Não foi apresentada & $100 \%$ & $68 \%$ & $66,70 \%$ & $15,90 \%$ & $27,50 \%$ & $91,70 \%$ & $37,50 \%$ \\
\hline $\begin{array}{l}\text { O processo requer } \\
\text { correção de } \\
\text { caderneta com } \\
\text { número distinto }\end{array}$ & - & - & - & - & $0,80 \%$ & - & $0,40 \%$ \\
\hline $\begin{array}{c}\text { Peça de defesa } \\
\text { padrão }\end{array}$ & - & $6 \%$ & - & - & $60,30 \%$ & - & $29,30 \%$ \\
\hline $\begin{array}{c}\text { Ausência de } \\
\text { documentação } \\
\text { necessária a ação }\end{array}$ & - & $4 \%$ & - & - & $6,90 \%$ & - & $3,90 \%$ \\
\hline $\begin{array}{l}\text { Não há oposição } \\
\text { ao pedido do autor }\end{array}$ & - & - & - & $2,90 \%$ & - & - & $0,70 \%$ \\
\hline $\begin{array}{c}\text { Ausência de erro } \\
\text { nos cálculos }\end{array}$ & - & $4 \%$ & $20,00 \%$ & $56,50 \%$ & $0,80 \%$ & - & $16,10 \%$ \\
\hline $\begin{array}{l}\text { Data dos benefícios } \\
\text { foi prescrita }\end{array}$ & - & - & - & $1,40 \%$ & - & - & $0,40 \%$ \\
\hline $\begin{array}{c}\text { Correções já } \\
\text { realizadas }\end{array}$ & - & $10 \%$ & $13,30 \%$ & $13,00 \%$ & $2,30 \%$ & $8,30 \%$ & $7,10 \%$ \\
\hline $\begin{array}{l}\text { Improcedência } \\
\text { do pedido do autor }\end{array}$ & - & $8 \%$ & - & $10,10 \%$ & $1,50 \%$ & - & $4,60 \%$ \\
\hline Total & $100 \%$ & $100 \%$ & $100 \%$ & $100 \%$ & $100 \%$ & $100 \%$ & $100 \%$ \\
\hline
\end{tabular}

Fonte: Autores. 
A "peça de defesa padrão" também foi encontrada, na pesquisa de campo, como “contestação padrão". Conforme as observações, tais peças eram pautadas pelos princípios da celeridade e da economia processual, com o fim de evitar que os processos seguissem a longa trajetória da primeira instância até as instâncias superiores ${ }^{20}$. Com essa linha de raciocínio, os juizados empregam um procedimento processual de julgar, de maneira mais rápida, tais demandas. O discurso observado em campo é que essas peças já são automaticamente depositadas em cartório, em favor dos réus - que, como já foi evidenciado, são compostos por sua esmagadora maioria pelo INSS e CEF, respectivamente -, caso haja sentença desfavorável a eles. Em nome da celeridade processual e de uma formação de jurisprudência com o fim de uniformizar decisões para pedidos tidos como iguais, no qual se alterariam apenas as partes, os juizados especiais federais construíram uma peça processual de uso automático para que os réus em suas ações não sejam prejudicados. E como foi possível constatar, tais peças padrão cumprem essa função, desencadeando 60,3\% dos casos arquivados, ou seja, negando pedidos aos reclamantes, que vão de aposentadorias a pensões e correção de benefícios, por exemplo.

Assim como em outras pesquisas, constatamos, a partir da observação de audiências e da construção de dados quantitativos, que as práticas processuais nesse contexto possuem linhas acentuadamente inquisitoriais (ANGELO; CARDOSO DE OLIVEIRA, 2021. IGREJA; RAMPIN, 2012). Se, de um lado, há um “tripé probatório bastante flexível, que é composto pela produção de prova documental, pela inquirição das partes autoras e das testemunhas e pela inspeção judicial” (ANGELO; CARDOSO DE OLIVEIRA, 2021), sem um padrão explícito²1, de outro, há certa padronização de defesa nas contestações automáticas, e com fé pública ${ }^{22}$, emprestada pelo cartório que produz tais peças, em face dos réus - compostos em sua

20 Atualmente, das decisões proferidas nos JEFs, 25\% chegam às turmas recursais. Veja mais em Justiça em Números 2020. Disponível em: <https://www.cnj.jus.br/wp-content/uploads/2020/08/WEB-V3-Justi\%C3\%A7aem-N\%C3\%BAmeros-2020-atualizado-em-25-08-2020.pdf>. Acesso em: 31 mar. 2021.

21 Em pesquisa já citada do IPEA, também foi constatado, em trabalho de campo, que era comum, em audiência nos JEFs, durante o depoimento de trabalhadores rurais, que os juízes não apenas voltam suas perguntas para a rotina do trabalho no campo, como também pediam para ver as mãos da parte, à procura de indícios de prova, como a calosidade das mãos, além de várias perguntas sobre produção agrícola (“em quanto tempo dá o milho?"; "qual a distância da sua casa pro roçado?”; "o senhor sabe a diferença entre a mandioca brava e a mandioca mansa?"; "quantos litros de leite tiram da vaca por dia?” etc.), para formarem suas convicções.

22 Fé pública é uma categoria jurídico que denota um crédito a ser dado, em razão de lei expressa, para documentos e certidões produzidos por certos servidores públicos ou pessoas com delegação do poder público no exercício de suas funções, reconhecendo-os como fidedignos a priori. Para aprofundamento do debate, ver LIMA, Roberto Kant de; MOUZINHO, Gláucia Maria Pontes. Produção e reprodução da tradição inquisitorial no Brasil: Entre delações e confissões premiadas. Revista Dilemas IFCS-UFRJ, v. 09, p. 505-529, 2016. 
esmagadora maioria pelo INSS e CEF, respectivamente -, em audiências que os desfavorecem, ato expresso na categoria nativa "peça de defesa padrão".

O fato de o juiz ocupar um lugar central e com autonomia (pelo livre convencimento motivado e pela independência no exercício da função jurisdicional), resulta em uma mitigação das normas que tratam do ônus da prova, uma vez que o convencimento do magistrado independe, na prática observada, das provas construídas ou requeridas pelas partes, uma vez que lhe é atribuído o poder de produzi-las e de analisá-las arbitrariamente. Sendo o "livre convencimento" um produto de aspectos voluntaristas e idiossincráticos de cada juiz, a verdade processual é construída através de um saber particularizado, e não de negociações entre as partes (TEIXEIRA MENDES, 2012, p. 153). Tal característica, inclusive, reforça a concepção inquisitorial presente no processo judicial brasileiro e instiga a (re)produção da lógica do contraditório nas práticas processuais no campo observado (ANGELO; CARDOSO DE OLIVEIRA, 2021) e em outros campos do direito (AMORIM; BAPTISTA; LIMA, M.; LIMA, R.; SILVA, 2021).

\section{CONSIDERAÇÕES FINAIS}

Embora imaginados a partir do modelo das Small Claims Courts (CARNEIRO, 1982), adotadas na Justiça dos Estados Unidos desde 1931, os juizados brasileiros ganharam feição própria, de modo a se ajustarem melhor ao ordenamento jurídico brasileiro. E pode-se dizer que suas principais diferenças residem nas características próprias dos sistemas judiciais norteamericano e brasileiro. Dessas diferenças resultam também distintas modalidades de prestação jurisdicional concedidas aos cidadãos pela justiça dos dois países, sobretudo por causa de distinções básicas entre as concepções processuais vigentes em seus respectivos ordenamentos jurídicos. Outras diferenças, como, por exemplo, a não existência de pequena corte criminal, nem a apreciação de dano moral nas Small Claims Courts dos Estados Unidos, oferecem distinções apreciáveis entre elas o os juizados brasileiros. Entretanto, embora a mediação não seja obrigatória nos Estados Unidos, as partes costumam aceitá-la livremente. Já no Brasil, a conciliação encerra fase estabelecida nas leis dos juizados, sendo, portanto, indispensável que as partes a ela se submetam. 
Tomando-se, por exemplo, a conciliação e a oralidade como critérios comparativos entre os próprios juizados brasileiros, já se constatou em muitas pesquisas que, nos juizados criminais dos Estados e nos cíveis federais, a conciliação fica inviabilizada. Os procedimentos processuais adotados na justiça criminal brasileira, por exemplo, são tutelados pelo Estado, e a natureza majoritária dos conflitos apreciados nos juizados criminais estaduais envolve, como já foi demonstrando em trabalhos anteriores (VIANNA; CARVALHO; MELO; BURGOS, 1999), relações entre pessoas próximas, o que dificulta conceder-lhes trato impessoal e padronizado para as demais situações que tratam de conflitos de natureza distinta da dos que se apresentam nesses juizados. Portanto, torna-se mais fácil obter acordo entre partes desconhecidas - como acontece nas relações de consumo apreciadas nos juizados cíveis estaduais - do que entre partes que mantêm relações próximas. Entretanto, nos juizados criminais estaduais, ocorre a oralidade nas Audiências de Conciliação, que geralmente são conduzidas por conciliador. Porém, nesses juizados criminais a transação penal é imposta (LIMA, M., 2017, p. 127-128; ALMEIDA, 2014, p. 162). Além de não ser realizada entre as partes, ela resulta da conciliação feita entre o acusado (autor do fato) e o Ministério Público, sendo a vítima excluída dessa transação. Se o autor do fato não aceita a transação, o processo irá para a Audiência de Instrução e Julgamento, na qual uma pena alternativa ser-lhe-á aplicada pelo juiz e, novamente, não sendo aceita ou descumprida pelo réu, este poderá ser processado, condenado e preso. A rigidez da legislação penal brasileira não poderia absorver a transação, muito menos entre as partes, embora concepções penalizantes e despenalizantes se contradigam acerca da transação penal introduzida pela Lei n ${ }^{\circ}$ 9.099/95.

No Brasil, a ação penal é uma obrigação do Estado ao tomar conhecimento de indícios de um fato criminoso. Não se trata de uma opção, mas de obrigação, não podendo o Estado desistir da ação penal após a sua propositura. Assim, no nosso sistema de justiça, o processo penal é uma prerrogativa obrigatória do Estado, com o fim de punir transgressões às normas preestabelecidas em lei, nas quais os acusados de algum crime devem comprovar sua inocência, ou seja, o ônus de comprovação de não culpabilidade é do acusado. Dessa forma, temos duas características importantes em nosso sistema de justiça criminal empiricamente observadas (LIMA, M., 2017, p. 180; LIMA, R., 2010, p. 41): o processo judicial, que é do Estado, e a inquisitorialidade, na qual quem chega à justiça criminal tem a priori alguma parcela de culpa no fato criminoso a ele atribuído, em que o acusado deve comprovar sua inocência. 
Dentro dessa lógica de funcionamento em que o Estado é ao mesmo tempo o dono do processo judicial e o acusador, e quem tem o ônus de comprovar sua inocência é o acusado, destaca-se a lógica do contraditório, na qual o acusado deve contradizer as acusações feitas pelo Estado como forma de defesa. O dissenso, o antagonismo de teses é a lógica de funcionamento do nosso sistema de justiça criminal.

Além disso, nosso sistema de justiça provém da tradição da Civil Law, que funda sua legitimidade em uma racionalidade abstrata, considerando os julgamentos técnicos dos juízes melhores que os de pessoas comuns, por deterem um saber jurídico especializado.

O juizado especial criminal, ao democratizar o acesso ao Judiciário para administrar conflitos oriundos de crimes de menor potencial ofensivo, acabou por reforçar uma inversão na lógica de funcionamento de nosso sistema. O "poder denunciante" da vítima se materializa quando ela se torna dona do processo judicial, e não mais o Estado. Empiricamente, perecebese que isso acaba por causar estranhamento e desconforto aos operadores do Judiciário, acostumados a lidar com um processo que é do Estado (LIMA, M., 2017, p. 180-181).

Assim, a respeito da transação penal, existem duas posições doutrinárias principais que podem figurar na prestação jurisdicional concedida pelo juiz do JECrim. Uma delas tem em conta que a transação penal, por ter sido acordada, é restritiva de direitos e não tem caráter condenatório ou absolutório. A outra considera que a pena restritiva de direitos vigente no JECrim tem natureza penal e, se descumprida, o juiz poderá aplicar a pena restritiva de liberdade. Têm-se, então, duas posições contraditórias a respeito da transação penal estabelecida na Lei ${ }^{\circ}$ 9.099/95.

Deste modo, autores de delitos previstos nesta lei e que recebem sentenças de privação de liberdade podem recorrer para as Turmas Recursais, e o julgamento de seus recursos permite observar a presença contraditória da jurisprudência que abriga ora uma, ora outra posição doutrinária (FERNANDEZ, 2003, p. 140-150). Da fase recursal, estão excluídas a conciliação e a oralidade para as partes, sendo a última permitida ao advogado do réu.

Já nos juizados cíveis federais, é muito rara a presença do conciliador. A conciliação fica praticamente abolida, sendo todo o procedimento judicial conduzido pelo magistrado (ANGELO, 2019, p. 9). A oralidade é extremamente restrita, exceto para as partes responderem às indagações ou atenderem aos esclarecimentos solicitados pelo juiz. Apesar de a Lei $\mathrm{n}^{\circ}$ 
10.259/01 abrigar a fase da conciliação, a indisponibilidade dos direitos e do patrimônio da União para os particulares é observada rigorosamente, o que inviabiliza a conciliação. Nas Audiências de Conciliação que foram acompanhadas durante a pesquisa, o juiz sempre pergunta às partes se há acordo. O representante da parte ré - procurador ou advogado do INSS ou da CEF - responde negativamente em todos os casos observados. O magistrado passa então para a Audiência de Instrução e Julgamento e indaga se a parte autora aceita ser acompanhada de um advogado, quando esta não contratou nenhum. Note-se que a presença do advogado das partes é dispensada em casos que envolvem valores menores que os fixados na Lei $\mathrm{n}^{\circ}$ $10.259 / 01$.

A parte autora muitas vezes hesita em aceitar a oferta, mas acaba concordando, mais em atenção ao juiz do que por estar convencida da necessidade de ter um advogado. Para atender a esta oferta, os advogados dativos circulam nos corredores ou nas próprias dependências do juizado.

Durante entrevistas realizadas com representantes do INSS e da CEF - seus advogados ou procuradores -, nas ações em trâmite nos juizados federais, estes operadores disseram que não podiam conciliar ou fazer acordos porque são responsáveis pelo patrimônio da ré e que estavam ali para protegê-lo, porque ele é público e inegociável com particulares. Assim, eles comparecem às audiências para resguardar o patrimônio da União, indisponível para acordos com particulares, não podendo este patrimônio ser tocado, sem que haja decisão judicial que o permita. A situação deixa o juiz federal como responsável maior pelo bem público, o que explicaria a oferta que faz à parte autora quanto à presença de advogado dativo para acompanhála, pois ela é vista como a parte mais fraca nas conciliações e, sobretudo, na fase de julgamento.

O trabalho de campo mostra que os jurisdicionados não conseguem estabelecer comunicação com a linguagem presente nos processos que lhes dizem respeito. Alguns juízes pacientemente lhes explicam a situação em termos acessíveis ao senso comum, ao passo que outros desconhecem a dificuldade. Em um caso observado, a autora não aceitou o advogado dativo e a juíza deu andamento à audiência de julgamento. Após expor o caso em tela, perguntou se a autora havia entendido, e esta respondeu que não.

A juíza entregou-lhe o processo para que fosse lido, mas a autora não conseguia entendêlo, pois lia com grande dificuldade. $\mathrm{O}$ marido dela, presente à audiência, foi em socorro da esposa, mas acabou sendo severamente repreendido pela juíza, sob a alegação de que somente 
a autora era parte do processo. A falta de comunicação entre a linguagem dos operadores e a linguagem dos jurisdicionados que recorrem aos juizados federais cíveis oferece considerável obstáculo à presença da oralidade nas audiências. Nos juizados federais cíveis, não há lugar prescrito para a comunicação das partes entre si nem, em muitos casos, entre estas e o magistrado.

Temos assim que, por distintas circunstâncias, a conciliação e a oralidade ficam limitadas nos juizados criminais estaduais (AMORIM; BURGOS; LIMA, R., 2003) e nos juizados cíveis da Justiça Federal (AMORIM, 2008). Nos primeiros, porque os conflitos de relações domésticas dificultam a conciliação e porque a transação e a pena descartam a presença da vítima. Nos segundos, porque a parte autora fica em posição assimétrica em relação à parte ré, esta detentora do direito que está sendo reivindicado.

Nos juizados federais criminais, as audiências são raras e poucas ações lhes são encaminhadas, comparadas com a elevada quantidade de reclamações nos juizados federais cíveis. Estes juizados criminais são chamados de "juizados adjuntos" por estarem instalados em dependências das varas federais criminais, e as audiências que realizam são bastante escassas. As ações neles predominantes envolvem conflitos entre funcionários públicos e particulares. Configuram conflitos distintos dos encontrados nos juizados federais cíveis porque não são conflitos diretos contra a União e, sim, tipicamente ações de particulares contra funcionários que a representam ou ações de funcionários contra particulares (ações de abuso de autoridade ou de desrespeito à autoridade). Nestes casos, os funcionários respondem pessoalmente em juízo, seja quando acusados, seja quando autores. As circunstâncias em que se encontram os atores nestas ações seriam favoráveis à conciliação; entretanto, ela raramente acontece.

Não apenas as dificuldades da conciliação nos juizados cíveis federais resultam da primazia que a União desfruta na prestação jurisdicional. Sempre que a justiça federal se viu diante de explosão da demanda, restringiu a conciliação, passando a admitir que ações que se referiam a direito líquido e certo dispensariam a conciliação, por tratarem de direito incontroverso. Depois, suprimiu as conciliações nos juizados de São João de Meriti (município da Baixada Fluminense) e de Niterói (município do Estado do Rio de Janeiro). Instalou juizados virtuais em São Gonçalo (município próximo a Niterói e ao Rio de Janeiro), o que também estaria ferindo o princípio da oralidade, sem falar no descumprimento legal da obrigatoriedade de conciliação, prevista na Lei ${ }^{\circ} 10.259 / 01$. 
Comparativamente, os juizados cíveis estaduais são os que ainda exibem condições relativamente mais favoráveis para abrigar a conciliação e a oralidade. Seja por lidarem com conflitos majoritariamente decorrentes de relações de consumo, em que a relação entre as partes é impessoal, seja por não haver direitos indisponíveis para nenhuma das partes, estando estas em condições mais favoráveis para negociar os legítimos interesses que reclamam do que no juizado cível da justiça federal.

Os juizados cíveis estaduais investigados contam com conciliadores que se esforçam por obter acordo entre as partes. Porém, a presença do dano moral interpõe situação que, muitas vezes, complica a negociação. Se, de um lado, o dano moral pode oferecer a oportunidade para que a ofensa a sentimentos seja reparada, de outro, alimenta a parte autora a enfatizar a ofensa recebida, a pleitear a desconsideração com que foi tratada pela parte ré - sobretudo quando a parte autora é assistida por advogado -, de modo a alcançar maior valor a receber na reclamação de que se considera vítima. A prestação jurisdicional nos juizados cíveis estaduais fica marcada pelo sentimento de desconsideração, e o dano material acaba separando-se do dano moral, como se este não fizesse parte daquele. Neste sentido, duas dimensões passam implicitamente a ser vistas no mesmo fato. Disso resulta que o dano moral tende a ser desprezado, sendo-lhe atribuído valor muito baixo nos juizados cíveis, o que acaba por desqualificá-lo e por banalizar o respeito que deveria ser preservado nos contratos presentes nas relações de consumo, nas quais trocas de bens e serviços estão sendo realizadas.

Críticas de que o dano moral se transformou em uma "indústria" nos juizados cíveis estaduais (e também na justiça civil comum) têm sido bastante enfatizadas, embora com intenções diversas do ponto de vista apresentado neste trabalho, que se refere apenas aos juizados cíveis estaduais e também aos cíveis federais. Tais críticas, geralmente endereçadas aos jurisdicionados, acabam também por atacar a imprecisão com que o dano moral está definido no ordenamento brasileiro ou, de outro modo, acabam por denunciar a desigualdade com que sua administração é concedida nas decisões judiciais.

Os conciliadores geralmente opinam na fase de mediação preliminar entre as partes e muitas vezes induzem a parte a aceitar a proposta que lhes parece mais justa, no que nem sempre são bem-sucedidos. Quando as partes não aceitam acordo mútuo, vão para a Audiência de Instrução e Julgamento. Nesta etapa da prestação jurisdicional - antes de ser marcada a respectiva audiência -, é permitido que os advogados (quando os há) apresentem arrazoado escrito ao juiz, em favor da parte que representam. Aberta a Audiência de Instrução e 
Julgamento, o juiz retoma os termos do desacordo, levando as partes ou seus representantes a exporem suas razões não conciliáveis. No intuito de ainda buscar conciliação, ele passa a opinar sobre o conflito, posicionando-se de acordo com o ordenamento comum, o que leva alguma das partes a aceitar acordo. Entretanto, esta aceitação mais decorre de estar o juiz manifestando uma possível tendência para julgar o conflito do que por estar a parte convencida daquilo que aceita.

Partes entrevistadas após as audiências manifestam-se diferentemente sobre os acordos que aceitaram e sobre as decisões que lhes foram endereçadas. Umas consideram-se bem atendidas, apesar de terem aberto mão de direitos (danos morais, em geral), pelo fato de o juiz as ter ouvido, avaliando esta atenção como mais importante do que a concessão do valor monetário requerido na ação, que, quase sempre, alcança o teto máximo permitido para indenizações morais nos juizados. Outras já reclamam do atendimento recebido e expressam desagrado, declarando não compreenderem por que a decisão contrariou seus interesses, por elas considerados dignos de apreciação.

Caso haja acordo, o juiz poderá proferir a sentença de imediato. Caso contrário, a sentença será expedida posteriormente e disponibilizada para as partes. Entretanto, independentemente do conhecimento oficial da sentença, as partes já parecem intuir se seus interesses foram acolhidos ou não na sentença. Em um dos casos acompanhados, a juíza insistia que o autor não detinha direito a dano moral porque, chamado pela $\mathrm{CEF}$, havia aceitado acordo extrajudicial e resolvido a feição material da questão, que se referia ao desaparecimento de dinheiro em sua conta, destinado à compra de um carro usado, negociação esta que havia sido acertada com o vendedor.

E, no ato de realizar o devido pagamento pelo veículo, o autor não dispunha do valor que estava depositado em sua conta na CEF. Saiu indignado da audiência, proclamando que havia passado vergonha por não ter o dinheiro para pagar pela compra acertada com o vendedor. Porém, posteriormente, foi verificado que a sentença judicial lhe havia concedido a quantia de $\mathrm{R} \$ 500,00$ pelo dano moral, a ser paga pela CEF, a ré.

Mesmo nos juizados cíveis estaduais, nos quais a conciliação entre as partes não é suprimida, não há regra explícita para a oralidade, embora as partes tenham oportunidade para se manifestarem oralmente, sobretudo na fase de conciliação preliminar. Uma tendência na adoção do procedimento usual na justiça civil comum vem sendo seguida, ou seja, as partes se manifestam quando o juiz permite, e o mesmo acontece com seus advogados. As partes não se 
comunicam entre si sem um interlocutor, seja ele o conciliador, seja o magistrado. Deste modo, os juizados chamados de "especiais" tendem a adotar procedimentos da justiça comum, o que aponta para a presença da força advinda da tradição jurídica brasileira, mais notável na justiça comum do que nos juizados, cujos procedimentos para eles prescritos, em muitos aspectos, rompem com a tradição.

A conciliação destacada na comparação entre as quatro modalidades de juizados brasileiros decorre do fato de estar ela presente, sobretudo na fase preliminar ao julgamento, e também porque seria ela uma espécie de lugar indispensável para a oralidade e para a comunicação entre jurisdicionados, e entre estes e os operadores jurídicos dos juizados. Além disso, a conciliação - e a oralidade como seu complemento - ofereceria momento privilegiado para que os jurisdicionados fossem socializados no direito de seu país, em situação que seus supostos legítimos interesses estariam sob apreciação judicial. Nesta visão, os juizados estariam não apenas concedendo maior acesso à justiça e ao direito, mas realizando uma importante política pública estatal que contribuiria para a internalização de normas jurídicas nos cidadãos que a eles recorrem para solucionar os conflitos que experimentam na sociedade.

De mobilizadores da democratização judicial e de instituições capazes de romper com concepções tradicionalmente arraigadas no direito e na justiça brasileiros, os juizados especiais vão se tornando mais caracterizados pelos parâmetros delimitadores de práticas judiciais tradicionais, minimizando ou suprimindo os procedimentos mais flexíveis que lhes foram atribuídos pela legislação que os criou e que permanece vigente. Imaginados como microssistemas capazes de provocar rupturas com o passado e de mitigar traços antirrepublicanos e antidemocráticos que ainda se insinuam no presente, estão os juizados brasileiros adotando padrões já ultrapassados na contemporaneidade e conciliando-se com a tradição (MELLO; BAPTISTA, 2011, p. 120).

Ainda estamos atravessando a "era dos direitos", um período que se enriqueceu com grandes avanços para a humanidade e que, longe de retroagir, inexoravelmente terá de prosseguir. Semelhantemente ao que ocorreu com o devido processo legal no Brasil (FERREIRA, 2004), os acordos e as conciliações, tanto nos juizados federais quanto nos estaduais, nem sempre servem para proteger o cidadão do Estado, mas sim o Estado do cidadão (AMORIM; BAPTISTA, 2014), algo explicitado, por exemplo, através dos usos da peça de defesa padrão no campo observado. 


\section{REFERÊNCIAS BIBLIOGRÁFICAS}

ALMEIDA, Vera Ribeiro. Transação Penal e Penas Alternativas: Uma Pesquisa Empírica nos Juizados Especiais Criminais do Rio de Janeiro. Rio de Janeiro: Lumen Juris, 2014.

ALVIM, J. E. Carreira. Juizados Especiais Federais. Rio de Janeiro: Forense, 2002.

AMORIM, Maria Stella de. BAPTISTA, Bárbara Gomes Lupetti. Quando direitos alternativos viram obrigatórios: burocracia e tutela na administração de conflitos. Antropolítica Revista Contemporânea de Antropologia, n. 37, 2014.

AMORIM, Maria Stella Faria de; BAPTISTA, Bárbara Gomes Lupetti; LIMA, Michel Lobo Toledo; LIMA, Roberto Kant de; SILVA, Fernanda Duarte Lopes Lucas da (orgs.). Dossiê: Pesquisa em Direito na Perspectiva Empírica: práticas, saberes e moralidades. In Antropolítica: Revista Contemporânea de Antropologia. Niterói. n. 51, 2021.

AMORIM, Maria Stella Faria de. Juizados Especiais em uma Perspectiva Comparada. Revista Ciências Sociais, Rio de Janeiro: PPGD-UGF, n. 2, v. 14, p. 175-188, 2008.

Juizados Especiais na Região Metropolitana do Rio de Janeiro. Revista Seção Judiciária do Rio de Janeiro - SJRJ, n. 17, p. 107-131, 2006.

LIMA, Roberto Kant de; BURGOS, Marcelo (orgs.). Juizados especiais criminais, sistema judicial e sociedade no Brasil. Niterói: Intertexto. 2003.

ANGELO, Jordi Othon; CARDOSO DE OLIVEIRA, Luís Roberto. Entre documentos, inquirições e inspeções: a trama da produção de provas em processos de aposentadoria rural nos Juizados Especiais Federais. In: Dossiê Pesquisa em Direito na Perspectiva Empírica: práticas, saberes e moralidades. Antropolítica: Revista Contemporânea de Antropologia. Niterói. n. 51, 2021.

ANGELO, Jordi Othon. Do ponto de vista dos(as) advogados(as): a produção de provas nos processos de aposentadoria por idade rural, nos Juizados Especiais Federais (JEFs), em SobralCE. In: VI Encontro Nacional de Antropologia do Direito, 2019, São Paulo. Anais VI Encontro Nacional de Antropologia do Direito, 2019.

AZEVEDO, Rodrigo Ghiringhelli de. Informatização da Justiça e Controle Social: Estudo Sociológico da Implantação dos juizados especiais criminais em Porto Alegre. São Paulo: IBCCRIM, 2000.

CARDOSO DE OLIVEIRA, Luís Roberto. Direito legal e insulto moral. Rio de Janeiro: Relume Dumará, 2002.

CARNEIRO, João Geraldo Piquet. "A justiça do pobre”. Revista AJURIS, n. 25, ano IX, julho, 1982, p. 69-70. 
CASTRO, Leopoldo Orsini de. O projeto de segmentação na Caixa Econômica Federal: A percepção do gerente. Dissertação de mestrado em Administração de Empresas. PUC-RJ, 2004.

FERNANDEZ, José Barros. A transação penal e suas consequências jurídicas. In: AMORIM, Maria Stella de; BURGOS, Marcelo; KANT DE LIMA, Roberto. Juizados especiais criminais: sistema judicial e sociedade no Brasil. Niterói: Intertexto, 2003.

FERREIRA, Marco Aurélio Gonçalves. O Devido Processo Legal: um estudo comparado. 1. ed. Rio de Janeiro: Lumen Juris, 2004.

GARAPON, Antoine. O Juiz e a Democracia. Rio de Janeiro: Editora Revan, 1999.

IGREJA, Rebecca Lemos; RAMPIN, Talita Tatiana. Acesso à Justiça na América Latina: reflexões a partir dos juizados especiais federais do Brasil. Revista de Estudos e Pesquisas Sobre as Américas, v. 6, p. 19-35, 2012.

IPEA - INSTITUTO DE PESQUISA ECONÔMICA APLICADA. Acesso à Justiça Federal: dez anos de juizados especiais. Brasília: Conselho da Justiça Federal, 2012, 228 p.

LIMA, Michel Lobo Toledo. A Formação do Conhecimento no Campo do Direito e das Ciências Sociais: Questões Teórico-Metodológicas. CONFLUÊNCIAS (NITERÓI), p. 41-63, 2015.

LIMA, Michel Lobo Toledo. Próximo da Justiça, Distante do Direito: administração de conflitos e demanda de direitos no Juizado Especial Criminal. Autografia: Rio de Janeiro, 2017.

LIMA, Michel Lobo Toledo. Que justiça seja feita: dilemas entre acesso à justiça, demandas e reconhecimento de direitos. ANTROPOLÍTICA: Revista Contemporânea de Antropologia, n. 45, p. 150-181, 2018.

LIMA, Roberto Kant de; MOUZINHO, Gláucia Maria Pontes. Produção e reprodução da tradição inquisitorial no Brasil: Entre delações e confissões premiadas. Revista Dilemas IFCSUFRJ, v. 09, p. 505-529, 2016.

LIMA, Roberto Kant de. Sensibilidades Jurídicas, Saber e Poder: Bases Culturais de Alguns Aspectos do Direito Brasileiro em uma Perspectiva Comparada. In: Anuário Antropológico, v. 2, p. 25-51, 2010.

MELLO, Kátia Sento Sé. BAPTISTA, Bárbara Gomes Lupetti. Mediação e Conciliação no Judiciário: dilemas e significados. Dilemas: Revista de Estudos de Conflito e Controle Social, v. 4, p. 97-122, 2011.

MENDES, Regina Lúcia Teixeira. Do princípio do livre convencimento motivado: legislação, doutrina e interpretação de juízes brasileiros. Rio de Janeiro: Lúmen Juris, 2012.

MOREIRA LEITE, Ângela. Em tempo de conciliação. Niterói: EdUFF, 2003.

NERI, Eveline Lucena; GARCIA, Loreley Gomes. Atrizes da roça ou trabalhadoras rurais? O teatro e a fachada para obtenção da aposentadoria especial rural. Sociedade e Estado, v. 32, p. 701-724, 2017. 
SILVA, Breno Inácio da. A representação social da transação penal: uma análise do grau de satisfação das partes. Dissertação de Mestrado apresentada ao Programa de Pós-Graduação em Direito da UGF. Rio de Janeiro, 2004.

SIMAS, Ulisses Fialho. O livre convencimento motivado dos juízes no novo código de processo civil. Dissertação (Mestrado em Direito) - Universidade Veiga de Almeida, 2020.

SOARES, Gláucio Ary Dillon. O Calcanhar Metodológico da Ciência Política no Brasil. Sociologia, Problemas e Práticas, n. 48, 2005, p. 27-52.

SOUZA, Érika Giuliane Andrade. Formas de Administração de Conflitos no Espaço Público: Casos de feijoada da polícia da cidade do Rio de Janeiro. Trabalho apresentado na 26a Reunião Brasileira de Antropologia, realizada entre os dias 01 e 04 de junho de 2007, Porto Seguro, Bahia, Brasil.

VIANNA, Luiz Werneck; CARVALHO, Maria Alice Rezende de; MELO, Manuel Palácios Cunha; BURGOS, Marcelo Baumann. A Judicialização da Política e das Relações Sociais no Brasil. Rio de Janeiro: Revan, 1999. 